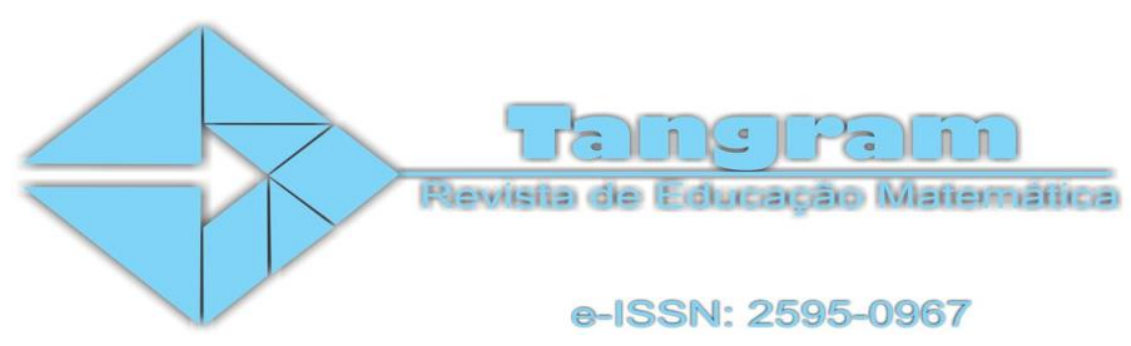

\title{
Modelagem Matemática e Educação Matemática Crítica: os protestos de 2013 e a tarifa de ônibus
}

\author{
Mathematical Modeling and Critical Mathematics Education: 2013 \\ protests and bus fare
}

\section{Modelación matemática y educación matemática crítica: las protestas de 2013 y la tarifa del autobús}

\author{
Claudia de Oliveira Lozada \\ Universidade Federal de Alagoas, Instituto de Matemática \\ Maceió, Alagoas, Brasil \\ e-mail: cld.lozada@gmail.com \\ Orcid: 0000-0003-1425-9956 \\ Ubiratan D’Ambrosio \\ Universidade Anhanguera de São Paulo, Educação Matemática \\ São Paulo, Brasil \\ e-mail: ubi@usp.br \\ Orcid: 0000-0003-0564-158X
}

Enviado:31/03/2020

Aceito:25/06/2020

DOI: 10.30612/tangram.v3i2.11325

Resumo: Este trabalho traz reflexões acerca da modelagem matemática e a Educação Matemática Crítica. Para tanto, trazemos como ponto de referência para essas reflexões os protestos em face do reajuste da tarifa de ônibus que ocorreram em 2013, centrando-se num contexto real que é a utilização do transporte público e o desenvolvimento de competências e habilidades que favoreçam o exercício da cidadania e da criticidade nas aulas de Matemática.

Palavras-chave: Modelagem Matemática. Modelos Matemáticos. Educação Matemática Crítica.

Abstract: This work brings reflections about mathematical modeling and Critical Mathematics Education. To this end, we bring as a reference point for these reflections the protests in the face of

Tangram - Revista de Educação Matemática, Dourados - MS - v.3 n.2, pp. 71-101 (2020)

Este obra está licenciada com uma Licença Creative Commons Atribuição-NãoComercial-CompartilhaIgual 3.0 Brasil. 


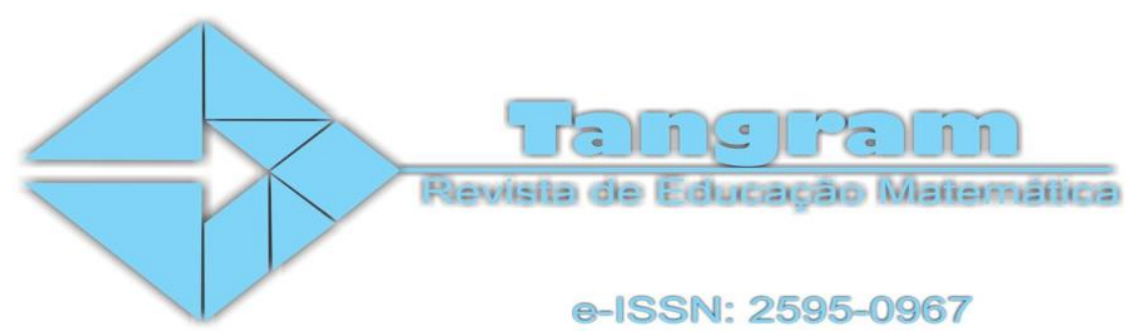

the readjustment of the bus fare that occurred in 2013, focusing on a real context which is the use of public transport and the development of skills and abilities that favor the exercise of citizenship and criticality in mathematics classes.

Keywords: Mathematical Modeling. Mathematical Models. Critical Mathematical Education.

Resumen: Este trabajo trae reflexiones sobre el modelado matemático y la educación matemática crítica. Con este fin, traemos como punto de referencia para estas reflexiones las protestas contra el reajuste de la tarifa del autobús que ocurrió en 2013, centrándose en un contexto real que es el uso del transporte público y el desarrollo de habilidades y habilidades que favorecen el ejercicio. ciudadanía y criticidad en las clases de matemáticas.

Palabras clave: Modelado matemático. Modelos matemáticos. Educación Matemática Crítica.

\section{Introdução}

Em 1984, o Brasil iniciava sua despedida do Governo Militar. O movimento "Diretas Já" invadiu as ruas, clamando por Democracia, restituição dos direitos civis que foram cassados durante a ditadura e por voto direto para presidente da República. Em 25 de janeiro de 1984, mais de 500 mil pessoas lotavam a Praça de Sé em São Paulo, bradando por eleições diretas para presidente da República. Ali fora realizado um comício histórico, com a presença de políticos e personalidades de destaque.

O deputado Dante de Oliveira havia proposto uma emenda à Constituição vigente com a finalidade de restabelecer as eleições diretas, mas esta não foi aprovada. No entanto, restava apenas à oposição tentar uma vitória nas eleições diretas no Colégio Eleitoral com a candidatura de Tancredo Neves. Tancredo foi o vencedor, mas um dia antes de tomar posse - em 14 de março de 1985 - foi internado às pressas e José Sarney assumiu interinamente a Presidência da República. Em 21 de abril de 1985, Tancredo Neves veio a falecer e Sarney foi empossado definitivamente como Presidente da República.

Em 15 de novembro de 1986, realizou-se eleição para a Assembleia Constituinte. O objetivo era eleger representantes para que elaborassem a nova Constituição do Brasil. A Assembleia Nacional Constituinte (Brasília) foi instalada em $1^{\circ}$ de fevereiro de 1987 e era composta por 559 parlamentares, dentre os quais 487 eram deputados e 72 eram senadores

Tangram - Revista de Educação Matemática, Dourados - MS - v.3 n.2, pp. 71-101 (2020) 


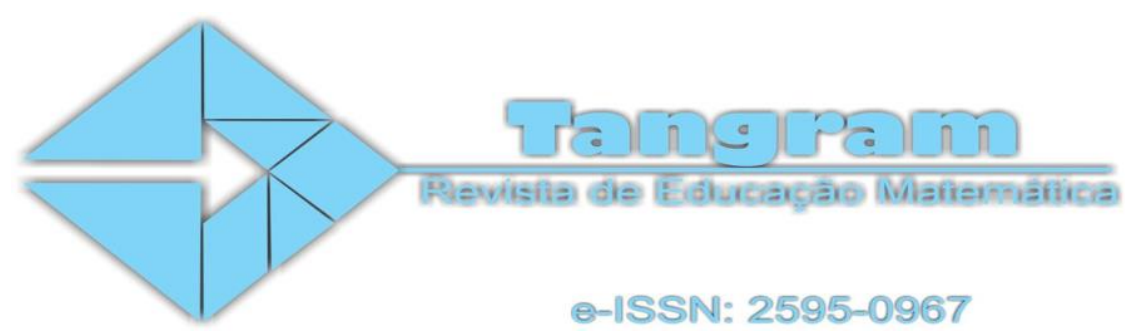

(Câmara dos Deputados, 2011). Ulysses Guimarães, político eminente e atuante no movimento "Diretas Já" abriu os trabalhos da Assembleia Nacional Constituinte com um discurso que ressaltava o compromisso da nova Carta Magna com a Democracia:

É um parlamento de costas para o passado este que se inaugura hoje para decidir o destino Constitucional do país. Temos nele uma vigorosa bancada de grupos sociais emergentes, o que lhe confere nova legitimidade na representação do povo brasileiro. Estes meses demonstraram que o Brasil não cabe mais nos limites históricos que os exploradores de sempre querem impor. Nosso povo cresceu, assumiu o seu destino, juntou-se em multidões, reclamou a restauração democrática, a justiça e a dignidade do Estado. (Guimarães, 1987, p. 01)

Após mais de um ano de trabalhos, finalmente em 5 de outubro de 1988, a nova Constituição do Brasil foi promulgada. Num discurso emocionado, o deputado Ulysses Guimarães, promulgou a Constituição cidadã, que resgatou os direitos dos cidadãos direitos individuais, sociais e políticos -, estabeleceu os remédios constitucionais (Habeas Data, Ação Popular, Ação Civil Pública, Habeas Corpus, Mandado de Segurança, Mandado de Segurança Coletivo, Mandado de Injunção) garantiu a independência dos poderes, elevou ao status constitucional o direito à Educação e ao Meio Ambiente ecologicamente equilibrado, além de resguardar o direito ao voto secreto e eleições diretas, bem como restituiu o Estado Democrático de Direito:

Ecoam nesta sala as reivindicações das ruas. A Nação quer mudar, a Nação deve mudar, a Nação vai mudar." (...) Há, portanto, representativo e oxigenado sopro de gente, de rua, de praça, de favela, de fábrica, de trabalhadores, de cozinheiros, de menores carentes, de índios, de posseiros, de empresários, de estudantes, de aposentados, de servidores civis e militares, atestando a contemporaneidade e autenticidade social do texto que ora passa a vigorar. (...) Não é a Constituição perfeita, mas será útil, pioneira, desbravadora. Será luz, ainda que de lamparina, na noite dos desgraçados. É caminhando que se abrem os caminhos. Ela vai caminhar e abri-los. Será redentor o caminho que penetrar nos bolsões sujos, escuros e ignorados da miséria. (...) A sociedade sempre acaba vencendo, mesmo ante a inércia ou antagonismo do Estado" (Guimarães, 1988, p.1)

Tangram - Revista de Educação Matemática, Dourados - MS - v.3 n.2, pp. 71-101 (2020) 


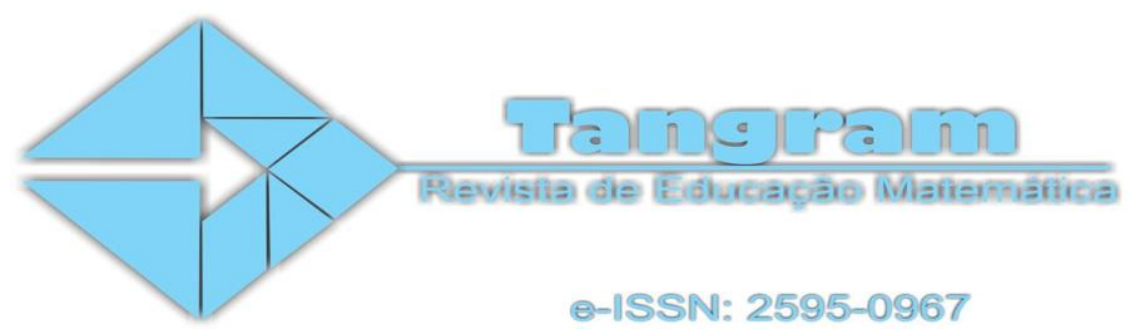

E assim, foi promulgada a Constituição Brasileira, que ficou conhecida como a Constituição Cidadã e que marcaria um novo momento para a sociedade brasileira.

A Constituição é a Carta Magna de um país que contêm princípios que regem toda a Nação e a vida de seus cidadãos, representa o ordenamento jurídico máximo e de acordo com os preceitos democráticos espelha a identidade do país e de seu povo, sua organização política e seus anseios. Numa democracia participativa como é a do Brasil, a Constituição de 1988 representou uma ruptura com o passado manchado pela brutalidade e cassação de direitos civis e constituiu a expressão que vinha das ruas no movimento "Diretas Já" que bradava por mudanças. No entanto, é a Constituição que mais emendas recebeu: 105 emendas, segundo dados de setembro de 2018 quando completou 30 anos.

É nesse contexto socio-histórico e político no qual a população teve participação ativa e decisiva na mudança dos rumos da Nação e na garantia dos direitos civis, em que os movimentos sociais evidenciaram o protagonismo social como um veículo integrante da democracia é que florescia a corrente jurídica denominada "O Direito Achado na Rua", na Faculdade de Direito da Universidade de Brasília na década de 80, por meio das ideias do Prof Roberto Lyra Filho e de seu aluno de Mestrado naquela época José Geraldo de Sousa Jr:

Estávamos em 1978, vim fazer o mestrado com o Lyra Filho. Estava interessado em trabalhar com uma proposta que se apoiava em alguns vetores para mim importantes. Primeiro, pensar o jurídico desde uma perspectiva politizadora. Marilena Chauí diria depois que o Lyra se caracterizou como uma espécie de dignidade política do Direito. (...) Então, me interessava esse processo porque a nossa inserção na plataforma das lutas democráticas fazia ver que o Direito era um Direito que cerceava as liberdades, não era emancipatório, era restritivo. O verdadeiro Direito tinha que emergir dessas lutas e se afirmar, às vezes inclusive contra legem, como reivindicação por liberdade e por justiça. (Sousa Jr, 2008b)

Para Lyra Filho, o Direito Achado na Rua "busca uma visão social do fenômeno jurídico" (Sousa et al, 2010, p. 45) superando a posição positivista/legalista do Direito, extraindo da realidade e da participação ativa dos sujeitos nas decisões da sociedade as bases para o Direito e não o contrário, como o Direito ditar as diretrizes para a realidade se

Tangram - Revista de Educação Matemática, Dourados - MS - v.3 n.2, pp. 71-101 (2020) 


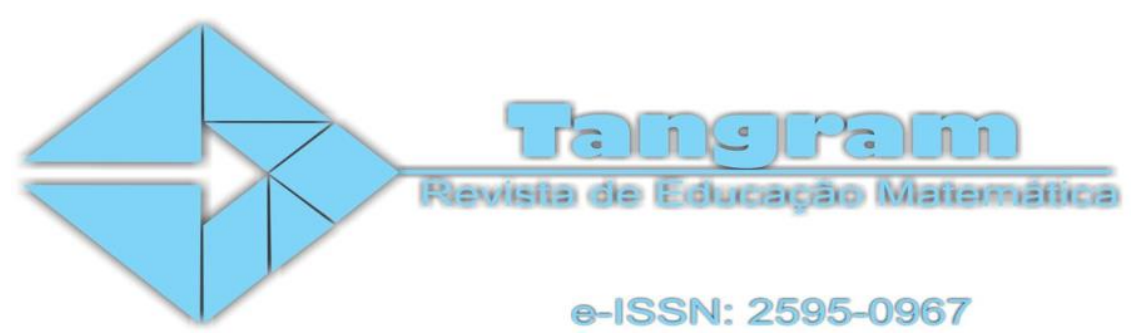

configurar em forma de lei, tendo o Estado como principal emanador das leis, num caráter hermético e restrito às discussões dos legisladores.

Com um olhar atento para a realidade, seu humanismo dialético via nas contradições humanas um processo dialético social construído por relações sociais (Oliveira, 2008) que se encaminhavam e apontavam no seu interior as soluções para as questões da sociedade, que posteriormente enfrentariam desafios para se concretizar ou não, mas que mesmo assim não reduziam ou ignoravam os avanços decorrentes de todo esse processo. Assim, Lyra Filho (2005, p. 287) pregava:

Uma vez que se trata de ciência normativa, humana e social, a ciência do Direito abrange, no seu coração mesmo, a convergência das raízes sociais, das incisões filosóficas e, até, do estremecimento religioso, desde o organismo humano, em suas bases físico-psíquicas aos problemas fundamentais do espírito, na superação das antinomias entre o homemproduto do meio e da base física e o homem incondicionado, entre o potencial de vontade livre e a efetividade das pressões internas e externas.

E a participação popular onde fica? É nesse cenário, no qual se configuram o exercício da cidadania e a participação ativa dos sujeitos é que se traduz a essência do Direito Achado na Rua:

Fala-se de O Direito Achado na Rua, caracterizando-o muito sucintamente, para aludir a uma concepção de Direito que emerge, transformadora, dos espaços públicos - a rua -, onde se dá a formação de sociabilidades reinventadas que permitem abrir a consciência de novos sujeitos para uma cultura de cidadania e de participação democrática. (Costa e Sousa Jr, 2009, p. 17)

O diálogo aparece então como uma condição precípua e singular nesses espaços onde o Direito se materializa pela dialética, entremeio aos anseios sociais numa construção coletiva, na existência do "sujeito coletivo de direito representado pelos movimentos sociais que se organizam e lutam no sentido da resolução de problemas que atingem a sociedade, propiciando avanços políticos e jurídicos” (Aguiar, 1994, p. 26 apud Sousa Jr, 2008a, p. 32). Ao longo da história do Brasil, os movimentos sociais têm participado ativamente dos

Tangram - Revista de Educação Matemática, Dourados - MS - v.3 n.2, pp. 71-101 (2020) 


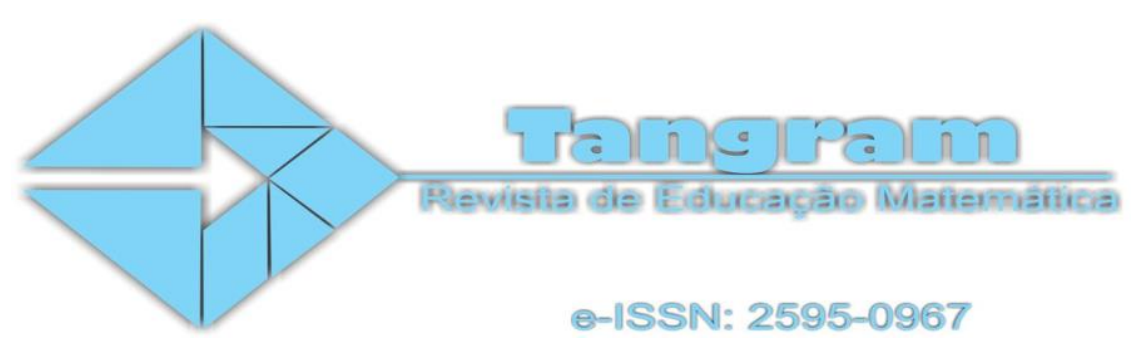

destinos da Nação, mobilizando os cidadãos para lutarem pelos direitos fundamentais, pela melhor distribuição de renda e, acima de tudo, pela manutenção da Democracia e da liberdade. Era também esta a visão de Freire (1970) quando reiterava em suas obras a necessidade de se formar um cidadão crítico e ativo, que pudesse participar dos debates sobre os diversos temas sociais e intervir em sua realidade para transformá-la, concepção esta seguida pela Lei de Diretrizes e Bases da Educação publicada em 1996, que teve como um de seus idealizadores, o educador Darcy Ribeiro, defensor da educação cidadã.

Os sucessivos protestos ocorridos nas últimas três décadas marcam essa característica do povo brasileiro de sair às ruas, se mobilizar, tornar a rua um espaço público onde os direitos emergem e se legitimam. A esse respeito Nalini (2008, p. 288) salienta que:

O cidadão brasileiro hoje é um protagonista da História. Tem todas as condições para alterar o rumo das coisas, seja na esfera da administração pública, seja no traçado das políticas destinadas à iniciativa privada. Mas precisa conhecer as ferramentas de participação e delas efetivamente se utilizar.

Esses atores sociais têm sido importantes e configuram as bases do Direito Achado na Rua:

Esta proposta está imbuída de um claro humanismo, pois toma o protagonismo dos sujeitos enquanto disposição para quebrar as algemas que os aprisionam nas opressões e espoliações como condição de desalienação e de possibilidade de transformarem seus destinos e suas próprias experiências em direção histórica emancipadora, como tarefa que não se realiza isoladamente, mas em conjunto, de modo solidário. (Sousa Jr, 2008a, p.5)

Nesse contexto de repensar a rua como um espaço democrático de emersão de vozes e de direitos, é que se repensa o papel da Matemática, da cidadania e da justiça social (D’Ambrosio, 2018).

A Matemática não está longe de emanar direitos e obrigações. A compreensão de seu papel na sociedade e dos mecanismos criados a partir dela como ferramenta de tomada de decisão e manutenção de poder, é um aspecto importante para não enxergá-la de maneira

Tangram - Revista de Educação Matemática, Dourados - MS - v.3 n.2, pp. 71-101 (2020) 


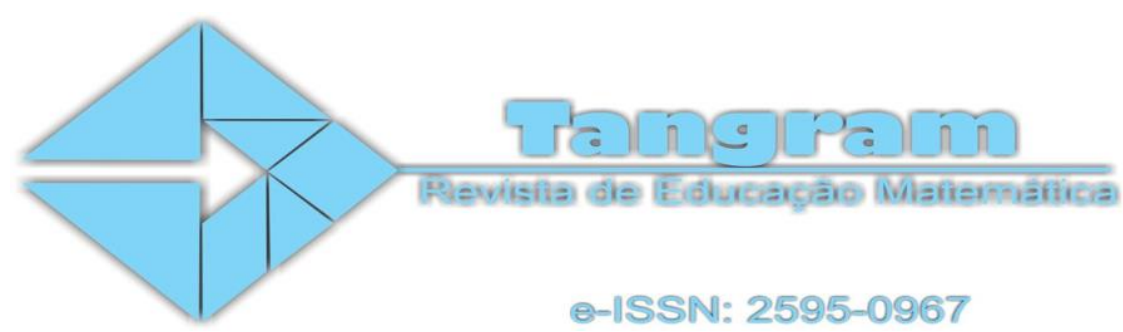

acrítica. Presente em diversos ramos da sociedade, seja de maneira mais evidente em alguns e menos evidente em outros, é essencial que seja vista como uma disciplina que exija aulas nas quais os alunos possam raciocinar e discutir problemas do cotidiano como um meio de se colaborar para a formação cidadã preconizada pelos documentos oficiais da educação nacional e a consolidação da Educação Matemática Crítica.

Os protestos de junho de 2013 que eclodiram no município de São Paulo em virtude do reajuste da tarifa de ônibus para $\mathrm{R} \$ 3,20$ se espalhando para outras cidades do país constituem um exemplo de mobilização pautada pelo exercício da cidadania e do Direito Achado na Rua, apresentando como protagonistas um perfil preponderantemente de jovens, e como pano de fundo um contexto matemático que poucos observam em relação à composição das tarifas e seus aumentos. No ano seguinte em 2014, as tarifas subiram em sete cidades brasileiras, como São Paulo e Rio de Janeiro, mas as vozes das ruas em 2013, não se apagaram e surgiram em outros momentos, por outras demandas e direitos.

Não nos cabe avaliar aqui os perfis políticos dos grupos que atuaram nas manifestações de junho de 2013, mas focar na participação cidadã e no papel da Matemática na sociedade.

Deste modo, este artigo trará reflexões acerca da modelagem matemática e a Educação Matemática Crítica tendo como cenário os protestos de 2013 contra o reajuste da tarifa de ônibus, balizando-se pelas ideias de Skovsmose, como veremos a seguir.

\section{Educação Matemática Crítica e a questão da cidadania: as ideias de Skovsmose}

No primeiro semestre de 2013, eclodiram diversos protestos pelo país. Com foco em São Paulo, o início das manifestações havia se dado em virtude do aumento da tarifa de ônibus. Entre a reinvindicação pela redução da tarifa, outras reinvindicações surgiram, exigindo melhorias na área de Educação, Segurança e Saúde.

Os jovens tomaram conta das ruas do país demonstrando sua insatisfação pela forma com que as políticas públicas estavam sendo conduzidas. Manifestação expressiva

Tangram - Revista de Educação Matemática, Dourados - MS - v.3 n.2, pp. 71-101 (2020) 


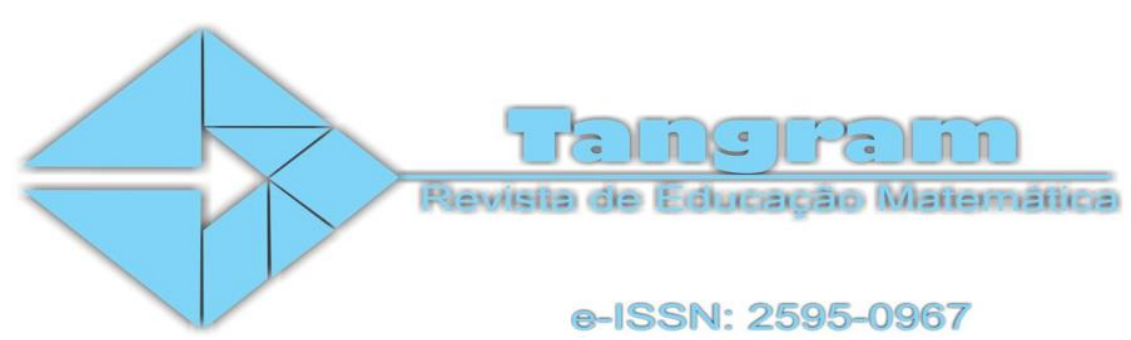

semelhante ocorrera em 1992 quando estudantes - conhecidos como caras pintadas - saíram às ruas para pedir o impeachment do presidente da República na época, Fernando Collor de Melo. Nestes dois momentos, a participação ativa da população destacou os pressupostos do Estado Democrático de Direito descrito no artigo $1^{\circ}$ da Constituição Federal de 1988 (chamada de Constituição Cidadã) -, marcado pela defesa da democracia e pelo exercício da cidadania:

À medida que a crise social desenvolve as contradições do sistema, emergem as conscientizações que apontam os seus vícios estruturais e surge um pensamento de vanguarda, que vê mais precisamente onde estão os rombos, superando a ideologia (...) (Lyra Filho, 2001, p. 21)

Mas, qual seria a relação da Matemática com aqueles protestos pela redução da tarifa de ônibus? Qual seria a relação da Matemática com o exercício da cidadania? Que competências devem ser desenvolvidas na escola que contribuam para o exercício da cidadania? Qual é o papel da Matemática para o desenvolvimento da democracia? De que maneira a Matemática afeta as nossas vidas?

Skovsmose (2001, p. 71) vai mais além e pergunta: “A educação matemática pode ser de valor em prover os alicerces para a posterior participação de crianças e adolescentes em uma vida democrática como cidadãos críticos?" Tal questionamento e tantos outros é que levaram Skovsmose (2008) a desenvolver um trabalho renomado sobre Educação Matemática Crítica. Segundo Passos (2008), a Educação Matemática Crítica surgiu na década de 70 na Europa e na década de 80 nos Estados Unidos. A autora explica que Skovsmose recebeu forte influência das ideias de Paulo Freire, da Teoria Crítica da Educação e dos trabalhos de D’Ambrósio sobre a Etnomatemática, para idealizar seu trabalho sobre Educação Matemática Crítica.

Skovsmose (2008) acredita que a Educação Matemática não é imparcial e nem inerte, ela se movimenta no contexto social e se entrelaça com a política e com o poder, influenciando nas decisões num mundo globalizado onde o conhecimento adquiriu um posto

Tangram - Revista de Educação Matemática, Dourados - MS - v.3 n.2, pp. 71-101 (2020) 


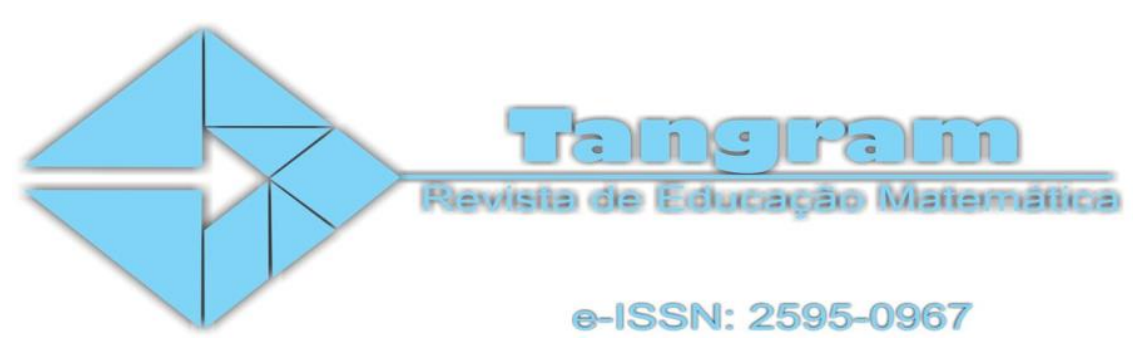

de destaque, porque conduziu a diversos avanços tecnológicos, e sustenta que "a matemática em ação pode produzir tanto horrores quanto maravilhas" (Skovsmose, 2008, p. 125).

É interessante colocar, que o autor tece críticas consideráveis à sociedade tecnológica e ao papel exercido pela Matemática nesta sociedade, pois como salienta “(...) a Matemática tem implicações importantes para o desenvolvimento e a organização da sociedade - embora essas implicações sejam difíceis de identificar” (2001, p. 40). Por esse motivo, é que o autor traz à tona a questão do aparato da razão, nascido no seio da complexidade, e que está predestinado a garantir a sobrevivência da tecnologia, pois pressupõe dos conhecimentos científicos - e a Matemática em ação é um dos campos do conhecimento que integra essa rede tecnológica - e tecnológicos aliados às necessidades do mercado e entrelaçados com as estruturas do poder, necessários ao desenvolvimento e manutenção da sociedade tecnológica (Skovsmose, 2007). Vale lembrar que Nicolescu (1999) também teceu severas críticas à sociedade tecnológica e lembramos que na ascensão da sociedade tecnológica é que se acentuou a degradação ambiental.

Evidentemente, foi nesse contexto da sociedade tecnológica, denominada por Castells (1999) como sociedade da informação, onde ocorreram mudanças profundas na economia e política global, bem como na forma de comunicação e nas relações humanas, que nasceu a quinta geração de direitos - os direitos virtuais. Estes inferem a regulação dos direitos na era digital (ou a tentativa de regulá-los), onde o domínio do uso dos meios tecnológicos e o uso frequente das redes sociais parece ser até mesmo uma condição precípua de ascensão tecno-social, e nesse cenário as indústrias disputam acirradamente o mercado de produtos inovadores e seus novos consumidores. Além do mais, a ascensão do uso da inteligência artificial com todo o seu poderio centrado em algoritmos que pressupõem vieses para selecionar perfis de consumidores e indicar ofertas, traz um cenário altamente competitivo entre as empresas, principalmente aquelas que se fundam na economia informacional (Skovsmose, 2005), onde o conhecimento e a informação são valores estratégicos para se atuar nesse cenário.

Tangram - Revista de Educação Matemática, Dourados - MS - v.3 n.2, pp. 71-101 (2020) 


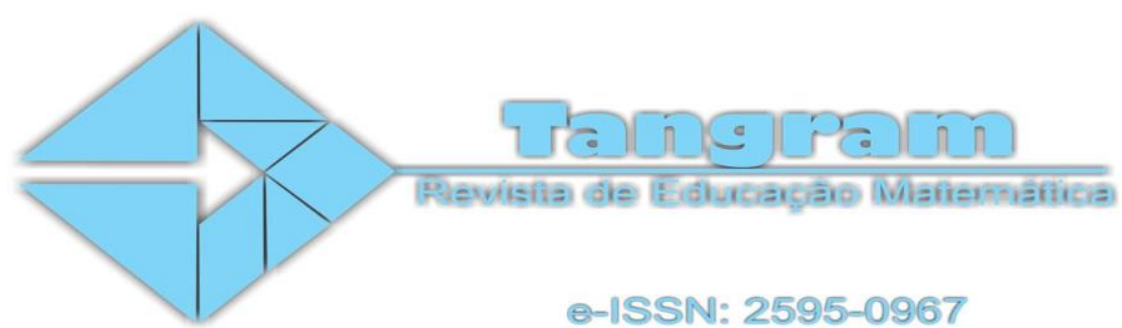

Mas, como esses produtos são desenvolvidos? Evidentemente, a Matemática aparece nesse cenário, desde o desenvolvimento dos produtos até mesmo na estimativa de sua venda, implicando em consequências de toda ordem na sociedade - políticas, econômicas, sociais as quais em grande parte das vezes não são perceptíveis pelos cidadãos. Nesse sentido, Skovsmose (2007, p.123) observa:

Por meio da matemática podemos representar algo ainda não compreendido e, portanto, identificar alternativas tecnológicas para dada situação. A matemática dá uma forma de liberdade tecnológica, abrindo um espaço para situações hipotéticas. Nesse sentido, a matemática se torna um recuso para a imaginação tecnológica e, portanto, para o planejamento de processos tecnológicos que incluem projeto-ação com base matemática.

Skovsmose (2001) acredita também que a Educação Matemática produz atitudes em relação à tecnologia, e que os estudantes passam a compreender que algumas pessoas dominam as questões relacionadas à tecnologia e outras não, tornando-se servis àqueles que possuem tal domínio, o que implica seriamente em problemas relacionados ao "processo de construção, organização e distribuição do conhecimento" (Skovsmose, 2007, p. 266) que caracteriza a sociedade da informação, juntamente com a globalização e a guetorização, apontadas pelo autor.

A julgar pela dualidade e ambiguidade com que fatos e situações se apresentam cotidianamente na vida humana, tanto o lado mais virtuoso quanto o lado mais sombrio podem se destacar, e não é diferente com a Matemática e nem com os sujeitos que fazem uso dela. Mas, a impressão que temos e que ficou em toda a sua trajetória como campo de conhecimento é que a Matemática é perfeita, incontestável e neutra. No entanto, como toda ciência, é também uma construção humana e não comporta perfeição, nem neutralidade, pois como esclarece Skovsmose (2008, p. 92) "transposições matemáticas criam a ilusão de que lidamos, de forma neutra e objetiva, com as coisas; de que deixamos de lado o domínio dos valores, do interesse político, das prioridades pessoais, etc."

Tangram - Revista de Educação Matemática, Dourados - MS - v.3 n.2, pp. 71-101 (2020) 


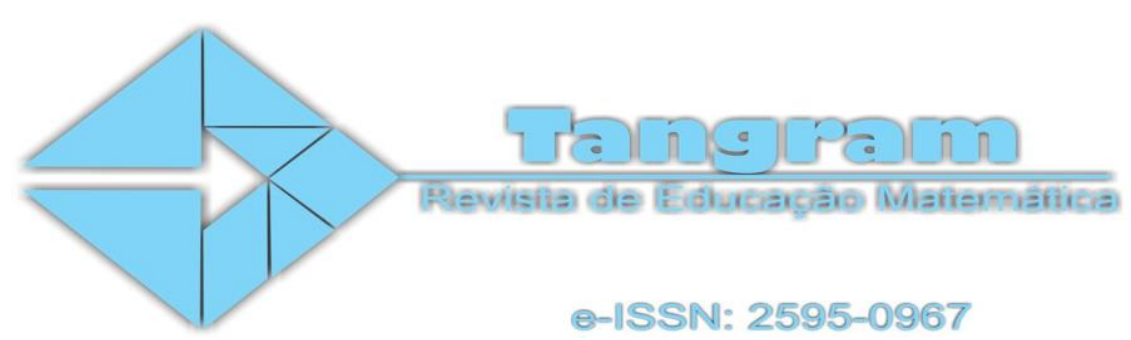

Com efeito, o que impera na maior parte das vezes é a imagem virtuosa de quem manipula o conhecimento matemático, acentuada pela ideologia da certeza como colocam Borba e Skovsmose (2001, p. 130), pois a visão que se tem é que "a Matemática é relevante e confiável, porque pode ser aplicada a todos os tipos de problemas reais". E desses problemas, surgem soluções evidenciadas pelos modelos matemáticos, vistos como "fórmulas" cujo sentido é conferido um caráter infalível, capaz de formatar comportamentos e interferir na realidade, pois como afirmam Borba e Skovsmose (2001, p. 135) "por meio de modelos matemáticos, também nos tornamos capazes de "projetar" uma parte do que se torna realidade".

Os autores ainda ressaltam que "tomamos decisões baseados em modelos matemáticos e, dessa forma, a Matemática molda a realidade”. Muitas decisões empresariais e governamentais, por exemplo, são tomadas com base em modelos matemáticos (Skovsmose, 2001) e possuem objetivos diversos como, por exemplo, a mitigação de danos ambientais até a prevenção de prejuízos e aumento do lucro, que envolvem receitas e orçamentos, além de investimentos. Essas decisões afetam várias áreas da sociedade e consequentemente o cotidiano dos cidadãos, além de implicarem em enorme responsabilidade por parte de que as toma, uma vez que geram efeitos, pois como enfatiza Skovsmose (2007, p. 249) “o poder exercido pela aplicação de um modelo matemático pode interagir com certos interesses políticos, prioridades econômicas ou preconceitos ideológicos".

Daí, Skovsmose (2008) falar em responsabilidade ética na tomada de decisões baseadas em modelos matemáticos e da necessidade da Matemática e da Educação Matemática serem objeto de reflexão crítica, e a escola tem parte nesse processo, uma vez que fica a seu cargo a alfabetização matemática. Para o autor, a "alfabetização matemática, (...) tem de estar enraizada em um espírito e crítica e em um projeto de possibilidades que habilite pessoas a participarem no entendimento e na transformação da sociedade". (Skovsmose, 2001, p. 95).

Tangram - Revista de Educação Matemática, Dourados - MS - v.3 n.2, pp. 71-101 (2020) 


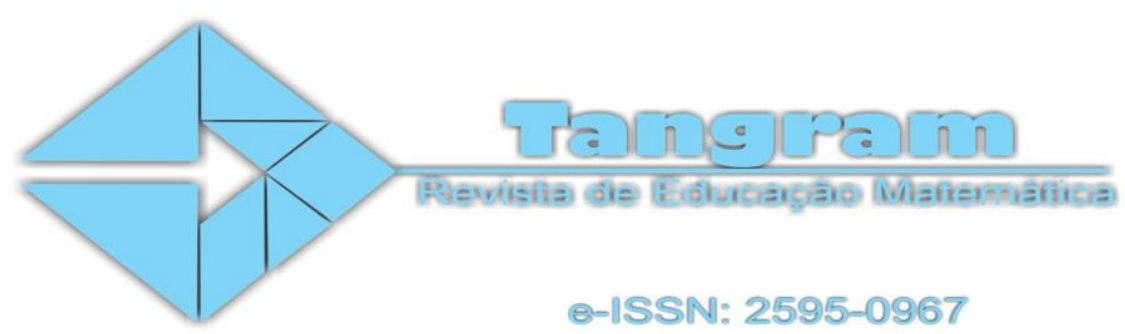

Além do mais, o autor tece considerações sobre a questão de que poucos têm conhecimento sobre as razões nas quais se fundam as decisões baseadas em modelos matemáticos, ficando o cidadão comum distante das decisões, formando assim dois grupos distintos: de um lado estão os governantes e a elite tecnológica e de outro estão aqueles que serão afetados pelas decisões. $\mathrm{O}$ autor deixa claro inclusive que o "acesso à modelagem matemática pode significar um acesso direto a certas formas de poder" (Skovsmose, 2007, p. 248).

Assim, a Matemática adquire um papel sociopolítico significativo (Skovsmose, 2007) na sociedade, influenciando na consolidação da democracia, uma vez que como afirma Skovsmose (2001, p. 83) “não apenas 'vemos' de acordo com a Matemática, nós também 'agimos' de acordo com ela". O autor segue afirmando que "as estruturas matemáticas vêm a ter um papel na vida social tão fundamental quanto o das estruturas ideológicas na organização social”.

Por isso, o autor advoga a favor da existência de uma educação crítica, afirmando que "a educação não pode apenas apresentar uma adaptação às prioridades políticas e econômicas (quaisquer que sejam); a educação deve engajar-se no processo político, incluindo uma preocupação com a democracia ${ }^{1}$ (2007, p. 19)". Por esta razão, Skovsmose

\footnotetext{
${ }^{1}$ Skovsmose (1992, p. 3-4) comenta sobre a democracia: "O conceito de democracia refere-se a um bouquet de diferentes ideias, esperanças e utopias. Consequentemente, embora seja impossível dar com precisão qualquer definição simples de democracia, poderíamos tentar captar o conceito, esquematizando ideias relacionadas com democracia. A democracia está relacionada, pelo menos, com os quatro aspectos seguintes: (1) Procedimentos formais para eleger um governo e para que o governo leve a cabo a sua governação. (2) Uma distribuição justa de serviços sociais e bens na sociedade, tais como, bem-estar, educação, hospitais, etc. Em consequência, uma parte substancial da análise teórica das ideias democráticas tem a ver com os tipos de bens e de facilidades que devem ser distribuídos de uma forma justa. E qual é a interpretação de "justo"? (3) Iguais oportunidades, direitos e obrigações para todos os membros da sociedade. Não podem existir diferenças de oportunidades baseadas em diferenças de origem social, sexo ou raça. Todos devem ser tratados de igual forma pela lei e, analogamente, todos devem obedecer à lei. Mas o que significa "igualdade de oportunidades"? De acordo com a tradição liberal e idealista, isto significa a possibilidade não limitada de cada um tentar fazer o que quer (legalmente) fazer; já a tradição materialista tem sublinhado que não é suficiente diminuir o número de limitações, isto é, a sociedade tem de proporcionar efetivamente as condições para que todos possam perseguir os seus interesses. Deste modo, toda a discussão sobre a democracia resulta numa discussão sobre a liberdade. (4) A possibilidade e a capacidade dos cidadãos participarem na discussão e avaliação das condições e consequências da governação que é levada a efeito: isto pressupõe uma "vida democrática". Para Skovsmose
}

Tangram - Revista de Educação Matemática, Dourados - MS - v.3 n.2, pp. 71-101 (2020) 


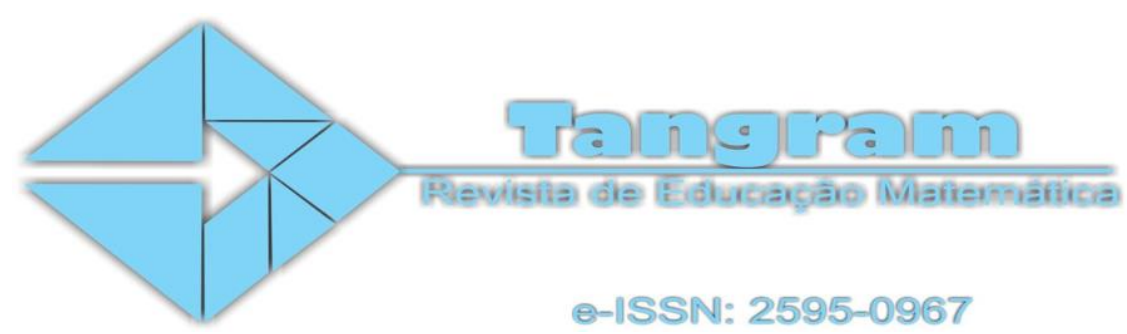

(2007, 2008) fala sobre a importância da alfabetização matemática contribuir para o desenvolvimento da competência democrática e da cidadania crítica, preceitos defendidos por Paulo Freire. Sendo assim, é necessário reformular a maneira como se ensina Matemática, enfatizando o aspecto dialógico da produção do conhecimento e o conhecimento reflexivo (Skovsmose, 2001). O autor recomenda a reflexão e a crítica sobre a Matemática em ação, pois segundo ele:

Reflexões tratam de algo real e público. Elas não estão apenas focalizando pequenas, mas diferentes, experiências pessoais. Quando as reflexões são dirigidas às ações, estão abrangendo mais do que experiências pessoais. Estão abrangendo eventos reais, e em muitos casos esses eventos afetam muitas pessoas. Em particular, a reflexão pode tratar da matemática em ação e o que pode ser feito por meio da matemática. Cálculos podem ser desenvolvidos e um modelo matemático (...) pode ser trazido à operação para esclarecer possíveis implicações de diferentes intervenções políticas e econômicas. E qualquer que seja a conclusão a que se pode chegar, as decisões têm que ser tomadas. A matemática é colocada em ação. A matemática se torna realizada e as reflexões podem ser encaminhadas ao que é realizado. (Skovsmose, 2007, p. 227, grifo nosso).

Para tanto, o autor acredita ser necessário reformular o currículo escolar a fim de incluir atividades com conteúdos que abordem questões da democracia como elemento que proporcione o exercício de direitos e deveres, pensados não apenas coletivamente, mas também de modo individual e que estimulem a criticidade e a reflexão por meio do diálogo. Esta possibilidade é vislumbrada instituindo-se cenários de aprendizagem onde os alunos são convidados a refletir sobre a Matemática, suas aplicações e seus impactos, bem como sua utilidade, pois “é importante para os alunos que eles possam discutir o que estão aprendendo, como estão aprendendo e a relevância do que estão aprendendo" (Skovsmose, 2008, p 65).

(2001, p. 78), “a democracia se refere não apenas às condições formais, mas também às condições materiais e éticas e às possibilidades de participação e reação." Ele afirma ainda que (...) a democracia pode ser destruída se não puder ser criada uma cidadania crítica." (op.cit)

Tangram - Revista de Educação Matemática, Dourados - MS - v.3 n.2, pp. 71-101 (2020) 


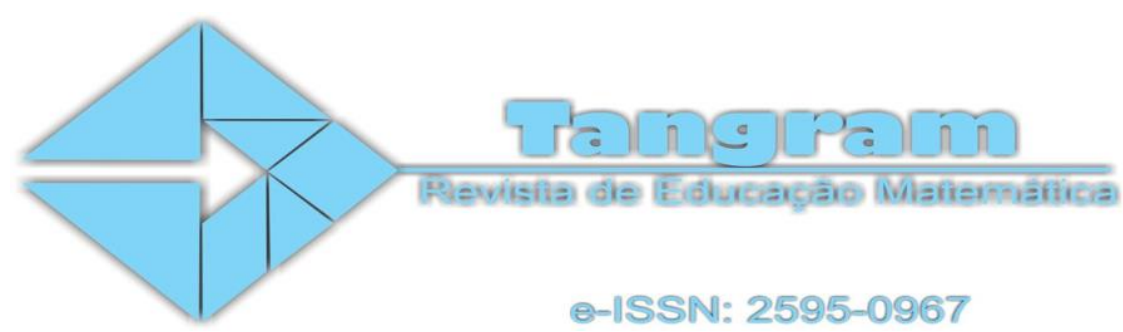

Por outro lado, o aspecto cultural chama atenção, uma vez que conceitos matemáticos são produzidos num contexto cultural, social e histórico onde a democracia está instituída ou está se desenvolvendo, razão pela qual D’Ambrosio (2003, p.3) defende a Etnomatemática:

\begin{abstract}
A teoria nos ensina a dar importância ao contexto e ao ambiente cultural no qual a matemática se desenvolve. Se os engenheiros da Embraer vão colocar um novo avião no mercado, eles usam a etnomatemática para aquele ambiente. Usam equações complexas para resolver situações de voo. Já as crianças jogando bolinha de gude estão em um ambiente que pede outra matemática específica. Eles pensam 'vou jogar assim com o dedão, qual será a trajetória da bolinha, qual força vou usar, qual a distância da outra bola', isso é matemática. $\mathrm{O}$ aluno que sai de casa e vai para a escola tem que traçar um trajeto, isso é etnomatemática adequada àquele ambiente, assim como o piloto de avião que sai de São Paulo e vai para o Rio. Ele usa a etnomatemática adequada para aquela situação. A teoria intervém na solução da situação que se apresenta e no conhecimento dessa situação. Mas a matemática que está na escola só reconhece as regras e formalismos desligados das reflexões mutáveis de acordo com o ambiente em que se está.
\end{abstract}

Por sua vez, Skovsmose (2001) critica arduamente a forma pragmática com que a modelagem matemática é praticada nas escolas, não permitindo aos alunos criticarem as atividades propostas para construção dos modelos matemáticos. Esta postura, segundo Skovsmose (op.cit) inviabiliza a oportunidade dos alunos investigarem detalhes que levaram à formulação do modelo, como, por exemplo, as variáveis que foram selecionadas e as relações que estabelecem entre si, e que possuem implicações sociais relevantes, pois influenciam nas decisões e geram efeitos, como já foi dito.

A crítica acerca da formulação dos modelos e suas implicações sociais é importante, pois como explica Skovsmose (2008, p. 115) “em muitos casos, parece que os modelos são usados para legitimar decisões já tomadas, fornecendo números e estatísticas que justificam a decisão" gerando o que ele denomina de "formas duvidosas de legitimação de decisões e ações" que são tomadas pelo governo e impactam seriamente nos valores democráticos e na sociedade. Ele cita como exemplo, os modelos matemáticos relacionados às questões que

Tangram - Revista de Educação Matemática, Dourados - MS - v.3 n.2, pp. 71-101 (2020) 


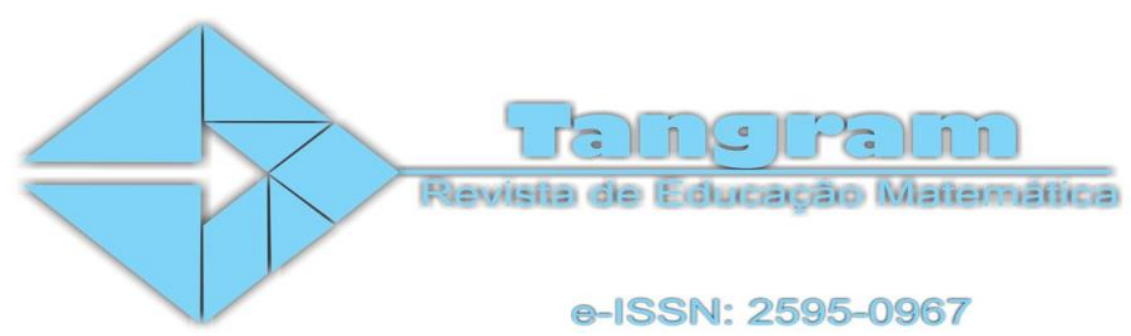

envolvem o trânsito em uma cidade e o meio ambiente em um projeto de construção de uma ponte, nos quais os modelos servem para tomada de decisões cujos efeitos podem ser irreversíveis.

Por esta razão, ele traz à luz alguns questionamentos que considera essenciais sobre os modelos matemáticos que estão a serviço do governo instituído e que devem ser esclarecidos: "Quem constrói os modelos? Que aspectos da realidade estão incluídos nesses modelos? Quem tem acesso aos modelos? Quem controla os modelos? Em que sentido é possível questionar e invalidar um modelo?”. Para ele, essas informações não devem ser omitidas da população, pois se trata de uma "responsabilidade ética" (Skovsmose, 2008) por ações baseadas em modelos matemáticos que afetam a vida em sociedade.

Por este motivo, Skovsmose (2007) critica a teoria da representação da modelagem matemática. Ele pontua que ocorre o processo de transposição matemática e que empregamos o verbo "representar não no sentido de criar uma cópia fiel ou um modelo de realidade, mas no sentido de reapresentar a realidade em um formato diferente", portanto, "a Matemática causa uma reconfiguração do mundo" (Skovsmose, 2008, p. 70). Esta ideia é corroborada quando o autor coloca que "a transposição matemática estabelece um novo mundo em termos da assim chamada descrição, e esse novo mundo pode aparentemente ser manipulado de modo adequado por meio de cálculos" (Skovsmose, 2008, p. 71).

Para o autor, a teoria da representação reduz a discussão da modelagem matemática à questão da representação, do uso da linguagem matemática na representação de aspectos da realidade, da exatidão dos modelos (bons e maus modelos, sendo que os bons representam bem a realidade) e de sua validação e desconsidera os contextos sociais e as consequências do processo de modelagem para a sociedade. A teoria da representação da modelagem matemática além de ser uma metáfora extremamente complexa, cercada de uma visão inocente da Matemática em ação, como bem observado por Skovsmose (2007), omite para a sociedade detalhes do processo de modelagem matemática.

Tangram - Revista de Educação Matemática, Dourados - MS - v.3 n.2, pp. 71-101 (2020) 


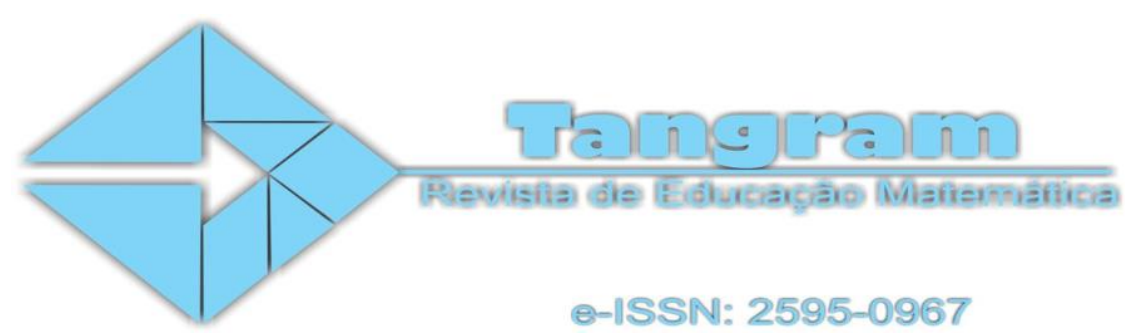

Esta posição não poderia ser diferente quando estão em jogo interesses de quem está no poder, pois há uma unilateralidade no processo de modelagem, no qual apenas uma parte da sociedade participa, seleciona as variáveis que comporão o modelo matemático de acordo com o que lhes convém. D’Ambrosio (2012) apresenta um esquema sobre a realidade e a estrutura do poder, como essa estrutura seleciona o que lhe interessa e como o conhecimento circula, é reformulado, assimilado e influencia, daí ser importante desenvolver uma consciência sobre a realidade que nos cerca e ter uma posição crítica que impulsione questionamentos sobre a estrutura do poder e os modelos matemáticos por ela gerados a partir de seus interesses.

E a questão da democracia, da participação, do bem comum? O modelo gerado por esta visão de modelagem representa qual realidade? Ou melhor, ele ajuda a formatar uma realidade, como dito anteriormente e trabalha a serviço de uma parcela da sociedade que colhe os benefícios e que não sofrerá tanto com os efeitos da aplicação desses modelos, porque sabem as consequências, portanto, também sabem os remédios para minimizar seus impactos. É um sentimento de desigualdade, imperceptível para o senso comum, mas que faz parte da Matemática em ação que sustenta também as estruturas do poder constituído que a manipula.

É nesse sentido, que D’Ambrosio (2007a) defende que a Educação Matemática seja acessível a todos, mas uma Educação Matemática de qualidade que proporcione condições de desenvolvimento intelectual igual para todos e verdadeiro acesso ao conhecimento.

Assim, o desejável, segundo Skovsmose (2007, p. 113) é que a modelagem matemática significasse "envolvimento, ação e mudança", mas para que isso ocorra seria necessário compreender o conhecimento matemático e as estruturas de poder. Por esta razão, Skovsmose (2001) insiste no desenvolvimento da competência democrática que estimula a participação e reação de todos na sociedade. E reafirma esta ideia, ao comentar sobre o argumento social da democratização:

Tangram - Revista de Educação Matemática, Dourados - MS - v.3 n.2, pp. 71-101 (2020) 


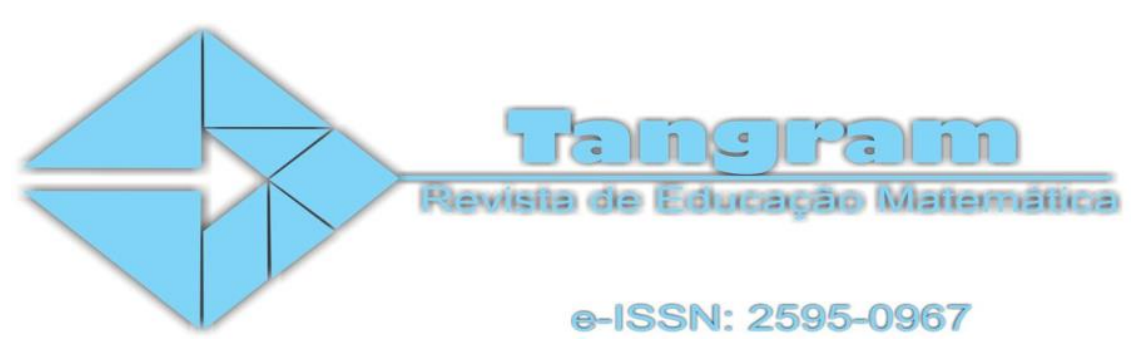

Para tornar possível o exercício dos direitos e deveres democráticos, é necessário estarmos aptos a entender os princípios-chave nos "mecanismos" do desenvolvimento da sociedade, embora eles possam estar "escondidos e serem difíceis de identificar. Em particular, devemos ser capazes de entender as funções de aplicações da matemática. Por exemplo, devemos entender como decisões (econômicas, políticas, etc) são influenciadas pelos processos de construção de modelos matemáticos. (Skovsmose, 2001, p. 41).

Deste modo é que se faz necessário repensarmos esta visão da modelagem matemática, sobretudo, nas escolas e nas universidades que se consagram como ambientes propícios para adoção da reflexão e da crítica sobre o processo de modelagem matemática, seu significado e suas implicações quando se trata de contextos reais, que devem contribuir para preparar os sujeitos para o exercício consciente da cidadania, sem uma visão romântica ou cega da aplicação da Matemática na sociedade. É preciso mais do que adquirir proficiência em Matemática, é preciso compreender as conjecturas implícitas no uso e na manipulação da Matemática por trás das cortinas do poder.

Por isso, alguns autores como Stillman (2012) defendem a prática de atividades de modelagem matemática baseadas numa perspectiva metacognitiva. Esta perspectiva aliada à perspectiva sociocrítica da modelagem poderão produzir resultados satisfatórios em relação à produção do conhecimento e a sua crítica, como operação fundamental do conhecimento reflexivo. Este é um caminho pelo qual se poderá desencadear o desenvolvimento de autonomia intelectual:

A autonomia intelectual é caracterizada em termos da consciência e da disposição dos alunos para recorrer às suas próprias capacidades intelectuais quando envolvidos em decisões e julgamentos matemáticos. A autonomia intelectual pode ser associada a atividades de exploração e explicação, como nos cenários para investigação. (Skovsmose, 2008, p. 37).

Em vista disto, há a necessidade de maior atenção por parte do professor no planejamento e desenvolvimento das atividades de modelagem, bem como na seleção dos

Tangram - Revista de Educação Matemática, Dourados - MS - v.3 n.2, pp. 71-101 (2020) 


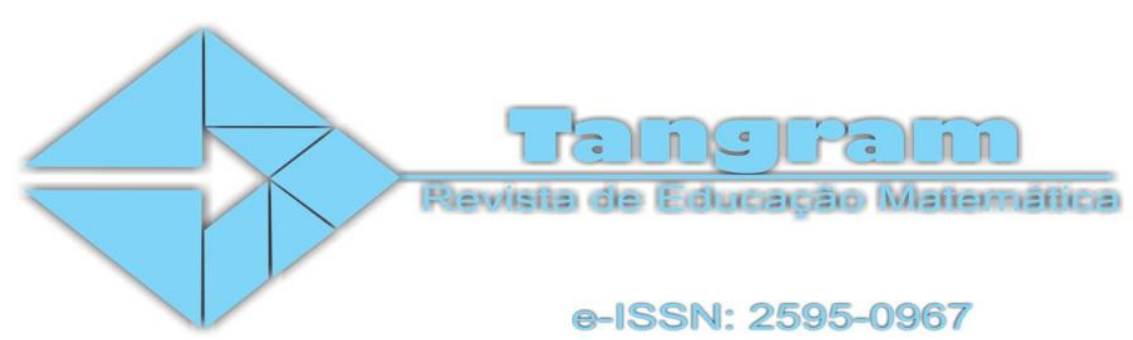

recursos didáticos utilizados. Skovsmose (2001, p. 43-44) elenca as características que o material didático a ser utilizado em atividades de modelagem deve possuir, os quais denominou de "materiais de ensino - aprendizagem libertadores": o material tem que ter relação com um modelo matemático real; o modelo tem a ver com atividades sociais importantes na sociedade; o material deve desenvolver um entendimento do conteúdo matemático, mas esse conhecimento, mais técnico, não é a meta. O autor (op.cit, p.43-44) esclarece que "a meta é desenvolver um insight sobre as hipóteses integradas ao modelo, e assim, desenvolver um entendimento dos processos (por exemplo, processos de decisão) na sociedade."

Silva, Barbosa e Oliveira $(2012,2013)$ defendem a adoção do que denominam de materiais curriculares educativos sobre modelagem matemática (MCEMM) que servem de apoio para os professores implantarem o ambiente de modelagem matemática na sala de aula. Estes, segundo os autores (op. cit), dizem respeito tanto à tarefa que será desenvolvida no ambiente de modelagem matemática agregando elementos das experiências do professor que o utiliza na sala de aula, como por exemplo, a solução do problema proposta pelos alunos, outros recursos didáticos utilizados pelo professor como vídeos, fóruns, etc.

A partir de tudo o que explanamos, é pertinente nos reportarmos àqueles fatos que narramos no início deste tópico: as manifestações ocorridas pela diminuição da tarifa do ônibus. Em julho de 2013, o IPEA (Instituto de Pesquisa Econômica Aplicada) divulgou um relatório que retrata que num período de 12 anos - de 2000 a 2012 - as tarifas dos ônibus aumentaram 192\%, um valor bem acima da inflação. Comparando-se com o preço da gasolina e dos veículos, o IPEA verificou que ambos tiveram reajustes abaixo da inflação para o mesmo período analisado (Matsuki, 2013).

Além do mais, na maioria das cidades brasileiras, o transporte público é financiado pelo valor cobrado com as tarifas, e envolve um encargo alto com mão de obra e combustíveis (Matsuki, 2013). Em 2013, assim como no ano anterior, o governo federal

Tangram - Revista de Educação Matemática, Dourados - MS - v.3 n.2, pp. 71-101 (2020) 


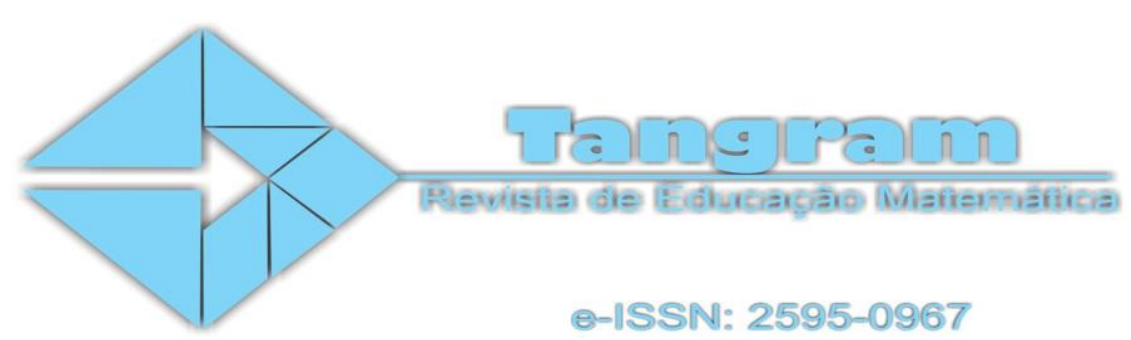

havia reduzido os impostos das empresas de transporte coletivo para permitir uma queda no valor da tarifa de ônibus urbano e/ou reajuste menor.

Em agosto de 2012, foi sancionado o Projeto de Lei de Conversão 18/2012 (MP 563), desonerando a folha de pagamento das empresas de transporte coletivo rodoviário (Planalto, 2013). A justificativa matemática acerca do impacto para as despesas dos usuários desse meio de transporte público foi a seguinte:

A redução de $20 \%$ sobre a folha de pagamento das empresas de transporte coletivo rodoviário equivale a $5,58 \%$ do faturamento. Subtraindo deste percentual o recolhimento de $2 \%$ de tributo sobre o faturamento das empresas, chega-se a um impacto de $3,58 \%$ de redução sobre as tarifas.

Mas, se a tarifa é reduzida, os lucros das empresas também são reduzidos. E quem de fato arca com o prejuízo? Em agosto de 2013, durante um evento, o prefeito de São Paulo, defendeu o aumento do preço da gasolina para custear a redução das tarifas do transporte público. O prefeito justificou-se afirmando que: "(Existia) aquele temor de que essa medida seria inflacionária. Não é. Os números demonstram que o impacto é deflacionário. A tarifa (de transporte público) pesa mais na cesta de produtos dos índices de inflação do que o preço da gasolina". Na ocasião, um estudo apresentando pela Fundação Getúlio Vargas de São Paulo, revelou que se houvesse um aumento de $\mathrm{R} \$ 0,50$ no litro do combustível na capital paulista, permitiria reduzir a tarifa de ônibus de $\mathrm{R} \$ 3,00$ para $\mathrm{R} \$ 1,80$.

Em outubro de 2013, o prefeito de São Paulo anunciou aumento do IPTU entre 20\% e 30\% para 1,3 milhão de imóveis, alegando que era uma forma de subsidiar o transporte público e manter o valor da passagem em R\$ 3,00 em 2014 (Jornal “O Estado São Paulo”, 2013). O cálculo do IPTU no município de São Paulo é baseado no valor venal do imóvel sobre o qual é aplicada uma alíquota e varia de acordo com a região da cidade. Para 2014, a Prefeitura de SP anunciou que os bairros localizados nas regiões centrais sofreriam maior aumento e aqueles localizados nas regiões periféricas sofreriam redução (Portal G1, 2013).

Tangram - Revista de Educação Matemática, Dourados - MS - v.3 n.2, pp. 71-101 (2020) 


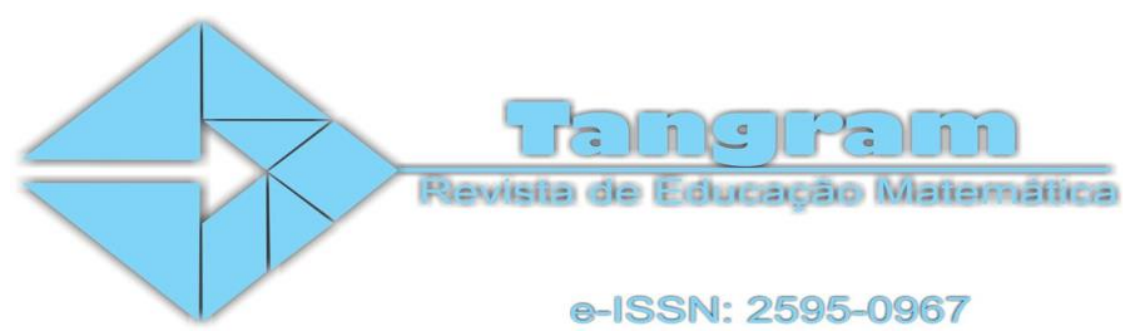

Embora o Ministério Público tenha ajuizado ação civil pública em face do Projeto de Lei que revisava a Planta Genérica de Valores (PGV) e definia os percentuais do aumento do IPTU e diversas liminares tenham sido postuladas para impedir o aumento, o Tribunal de Justiça de São Paulo suspendeu os efeitos de uma das principais liminares - a $7^{\text {a }}$ Vara da Fazenda Pública da Capital - alegando lesão à ordem pública, uma vez que reduziria a arrecadação do município, trazendo impactos para as áreas de Saúde e Educação. Em dezembro de 2013, o STF negou o pedido da prefeitura de São Paulo para restabelecer o aumento do IPTU (Revista Exame, 2013). Essa questão torna bem claro o papel da Matemática na sociedade, os interesses que envolvem uma determinada questão e que geram decisões que afetam a todos e nem sempre agradam a todos, daí Skovsmose (op.cit) insistir na competência democrática em seus trabalhos, pois ela desencadeia o exercício da cidadania.

Retornando ao cálculo do valor da tarifa do ônibus, este envolve uma série de elementos como, por exemplo, combustível, pneus, pagamento da folha salarial, depreciação dos veículos, frota, tributos, peças e acessórios, entre outros. A tarifa corresponde ao rateio do custo total dos serviços entre os passageiros pagantes. Os pagantes custeiam a tarifa dos usuários beneficiados com a gratuidade. O IPEA (2013, p. 12) explica que "para se calcular o impacto das gratuidades, soma-se o volume das gratuidades e das passagens com descontos ao volume de demanda pagante na fórmula e calcula-se o novo valor médio da tarifa". Outro exemplo de custo duplo para o usuário está no bilhete único utilizado no município de São Paulo, conforme nota técnica publicada pelo IPEA (2013, p. 12-13) em julho de 2013:

Fixando um valor único para a tarifa com direito a várias integrações no período de duas horas, observa-se que os usuários que se deslocam em distâncias curtas, utilizando apenas uma linha, subsidiam quem utiliza mais de uma linha no período de tempo. Em 2007, (...) , cerca de $60 \%$ dos usuários utilizavam apenas uma linha nos seus deslocamentos. Sem dúvidas há grandes benefícios para a população com a implementação da integração temporal, mas o que se discute é quem deve financiar isso.

Tangram - Revista de Educação Matemática, Dourados - MS - v.3 n.2, pp. 71-101 (2020) 


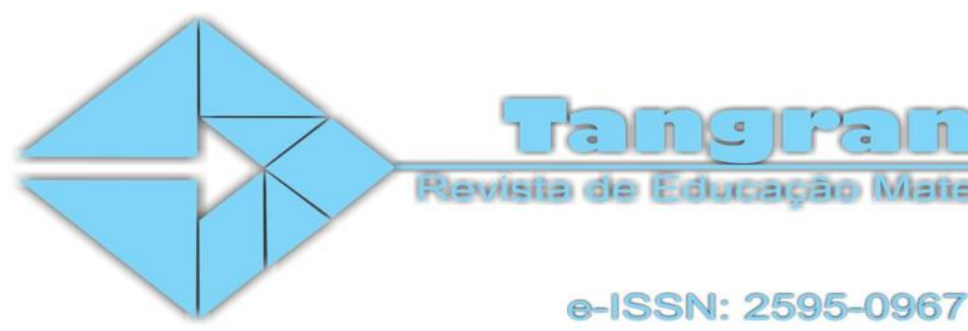

A seguir, apresentamos um modelo matemático para calcular o valor da tarifa utilizado pela Prefeitura de Porto Alegre (RS) que utiliza uma metodologia desenvolvida pelo GEIPOT/EBTU - Grupo de Trabalho, coordenado pela Empresa Brasileira de Planejamento de Transportes. Essa metodologia foi desenvolvida em 1982 sendo atualizada periodicamente e é utilizada pela maioria das cidades brasileiras. $\mathrm{O}$ modelo matemático abaixo demonstra como é constituída a tarifa de ônibus no município de Porto Alegre:

$$
T A R=\frac{(C F+C V) x\left(100-\frac{T}{100}\right)}{I P K}(1)
$$

Onde: TAR: Tarifa; CF: Custos Fixos; CV: Custos Variáveis; T: Tributos; IPK: Índice de passageiros transportados por quilômetro

Fonte: Prefeitura Municipal de Porto Alegre - Manual de cálculo da tarifa de ônibus de Porto Alegre (2013, p. 10)

\section{Fig. 1 - Exemplo de composição da tarifa de ônibus}

No entanto, há vários elementos que envolvem o modelo matemático do reajuste da tarifa de ônibus. A seguir, demonstramos o modelo matemático utilizado pela Prefeitura do Rio do Janeiro e a redução ocorrida na tarifa no mês de junho de 2013:

\section{Tabela 1 - Reajuste de tarifa de ônibus}

\begin{tabular}{|c|c|c|c|c|}
\hline \multicolumn{5}{|c|}{ 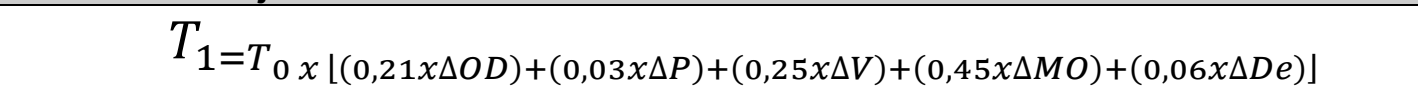 } \\
\hline \multicolumn{5}{|c|}{$\Delta \mathrm{OD}=$ variação do valor de óleo diesel (IPA-FGV): $22,58 \%$} \\
\hline \multicolumn{5}{|c|}{$\Delta P=$ variação do valor de pneus para ônibus e caminhões (IPA-FGV): 7,07\% } \\
\hline \multicolumn{5}{|c|}{$\Delta \mathrm{V}=$ variação do valor de veículos pesados para transporte (IPA-FGV): $2,67 \%$} \\
\hline \multicolumn{5}{|c|}{$\Delta \mathrm{MO}=$ variação do valor de mão de obra (INPC- IBGE): $9,57 \%$} \\
\hline \multicolumn{5}{|c|}{$\Delta \mathrm{De}=$ variação de outras despesas (INPC-IBGE): 9,57\% } \\
\hline PERÍODO & MESES & $\begin{array}{l}\text { \% ACUMULADO } \\
\text { REAJUSTE }\end{array}$ & TARIFA (R\$) & $\Delta$ TARIFA (R\$) \\
\hline Dez/11 a Dez/12 & 12 & $6,11 \%$ & 2,918 & 0,168 \\
\hline Dez/12 a Mai/13 & 5 & $4,14 \%$ & 3,039 & 0,121 \\
\hline Total & 17 & $10,50 \%$ & 3,039 & 0,289 \\
\hline
\end{tabular}

Tangram - Revista de Educação Matemática, Dourados - MS - v.3 n.2, pp. 71-101 (2020) 


\begin{tabular}{|c|c|c|c|c|}
\hline \multicolumn{5}{|c|}{ e-1SSN: 2595-0967 } \\
\hline FAIXA & $\begin{array}{c}\text { VALOR ATUAL } \\
\text { DA PASSAGEM } \\
\text { (R\$) }\end{array}$ & $\begin{array}{c}\text { VALOR } \\
\text { REAJUSTADO } \\
\text { DA PASSAGEM } \\
(\mathbf{R} \$) \\
\end{array}$ & $\begin{array}{c}\text { QTDD } \\
\text { PASSAGEIROS/MÊS }\end{array}$ & RECEITA (R\$) \\
\hline $\mathbf{A}$ & 2,75 & 3,039 & 79.166 .229 & 240.586 .170 \\
\hline B & 2,85 & 3,150 & 925.797 & 2.916 .261 \\
\hline C & 3,10 & 3,426 & 1.333 .812 & 4.569 .640 \\
\hline D & 3,30 & 3,647 & 1.246 .641 & 4.546 .500 \\
\hline $\mathbf{E}$ & 3,40 & 3,757 & 490.278 & 1.841 .974 \\
\hline $\mathbf{F}$ & 5,40 & 5,967 & 246.910 & 1.473 .312 \\
\hline Total & & 3,068 & 83.409 .667 & 255.933 .857 \\
\hline \multicolumn{5}{|c|}{$\begin{array}{l}\text { Desoneração do Pis/Cofins } \\
\text { O Pis/Cofins incidia na alíquota de } 3,65 \% \text { sobre o faturamento }\end{array}$} \\
\hline $\begin{array}{c}\text { QTDD } \\
\text { PASSAGEIROS/MÊS }\end{array}$ & $\begin{array}{c}\text { VALOR } \\
\text { REAJUSTADO } \\
\text { DA PASSAGEM } \\
(\mathrm{R} \$)\end{array}$ & RECEITA (R\$) & $\begin{array}{l}\text { CÁLCULO } \\
\text { PIS/COFINS }\end{array}$ & PIS/COFINS/PASSAGEM \\
\hline 83.409 .667 & 3,068 & 255.933.857 & 9.341 .585 & 0,112 \\
\hline \multicolumn{5}{|c|}{ Desta forma, a tarifa foi reduzida em $R \$ 0,112$. Nova tarifa de $R \$ 2,956}$. \\
\hline
\end{tabular}

Dessa forma, vimos que a Matemática e a modelagem matemática envolvida no cálculo do valor das tarifas do transporte público traz uma rede de significados que muitas vezes são desconhecidas da população, que neste caso é quem mais sofre com os efeitos dos reajustes. Muitas prefeituras disponibilizam relatórios sobre como o cálculo da tarifa de ônibus e de seu reajuste são realizados, portanto, a população tem acesso aos dados de composição da tarifa, mas não têm o hábito de consultá-la com periodicidade e nem de compreender quais insumos a compõem, e o que poderia ser feito (matematicamente e considerando os setores e sujeitos que são impactados) para evitar aumentos drásticos e desproporcionais que a população que utiliza o transporte público não consiga suportar.

No entanto, o transporte público no Brasil carece de melhorias, pois é considerado de péssima qualidade e com custo alto, sendo necessários investimentos e melhor aplicação dos recursos para que se torne eficiente. E cabe à população fiscalizar e exigir que o poder público e seus representantes administrem melhor esses recursos e ofertem um transporte de qualidade com tarifas justas.

Tangram - Revista de Educação Matemática, Dourados - MS - v.3 n.2, pp. 71-101 (2020)

Este obra está licenciada com uma Licença Creative Commons Atribuição-NãoComercial-CompartilhaIgual 3.0 Brasil. 


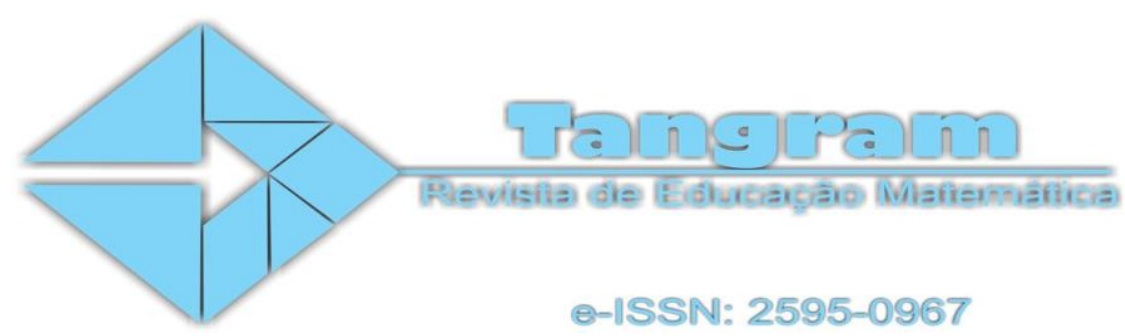

Portanto, as manifestações que ocorreram em junho de 2013 e tomaram as ruas do país foram legítimas, pois espelharam os princípios democráticos e expressaram a competência crítica sobre a Matemática em ação e o exercício da cidadania, sobre um direito achado na rua. O impacto que o reajuste da tarifa teria nas despesas dos trabalhadores e estudantes que utilizam o transporte público seria enorme, assim como teria também um impacto expressivo para a arrecadação das empresas de ônibus, considerando que o aumento de vinte centavos é bastante no município de São Paulo que possui um número elevado de usuários diariamente e tarifas integradas com metrô e trem.

Por este motivo, é essencial que as instituições de ensino - desde o nível básico até o superior - promovam a aprendizagem significativa crítica (Moreira, 2005; Silva, 2011) que contribui para o desenvolvimento do pensamento crítico (Ennis, 1991, 1993, 1996, 2011) e da Educação Matemática Crítica. Nesse sentido, o desenvolvimento do pensamento científico, crítico e criativo é postulado pela Base Nacional Comum Curricular - BNCC (Brasil, 2018, p. 09), como uma de suas dez competências gerais, como podemos ver:

Exercitar a curiosidade intelectual e recorrer à abordagem própria das ciências, incluindo a investigação, a reflexão, a análise crítica, a imaginação e a criatividade, para investigar causas, elaborar e testar hipóteses, formular e resolver problemas e criar soluções (inclusive tecnológicas) com base nos conhecimentos das diferentes áreas.

A criticidade já era um aspecto amplamente defendido em outros documentos oficiais da Educação, e na BNCC, foi estendida também à utilização e criação de tecnologias digitais, agregando-a de forma significativa, reflexiva e ética, nas diversas práticas, sejam sociais ou escolares (considerando-se todas as disciplinas curriculares), nas quais se comunicam, acessam e disseminam informações e se produzem conhecimentos, uma vez que vivemos em uma sociedade em que há o uso massivo das redes sociais e tecnologias móveis, além da presença da inteligência artificial, sendo que estas considerações não devem se limitar apenas às aulas de Matemática, mas ampliá-las para as outras disciplinas e temas transversais.

Tangram - Revista de Educação Matemática, Dourados - MS - v.3 n.2, pp. 71-101 (2020) 


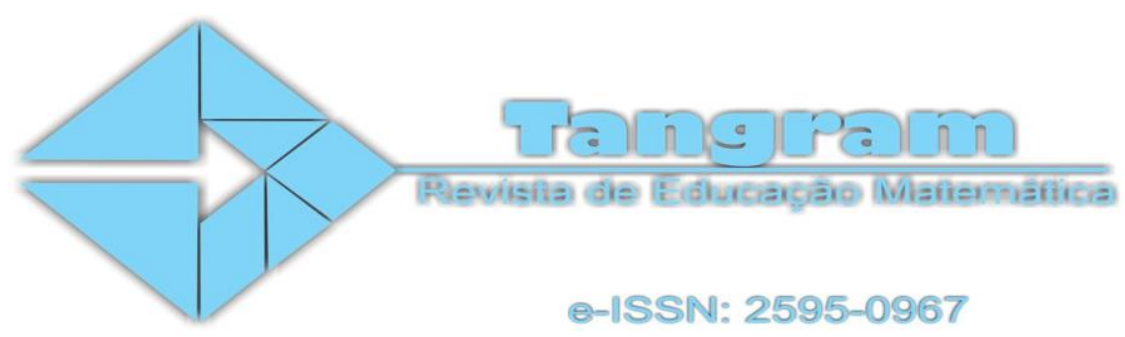

\section{Considerações finais}

A reflexão sobre a prática exige um esforço contínuo para que se materialize em ação. Tornar as aulas de Matemática focadas em temas do cotidiano exige uma mudança profunda na preparação das aulas e na utilização de diferentes recursos didáticos, sobretudo, quando se postula por uma Educação Matemática Crítica, que exige protagonismo por parte do aluno e uma postura mais ativa do professor no sentido de promover indagações (não apenas sobre o conhecimento matemático, mas sobre os impactos do uso da Matemática na sociedade) e desafios durante as atividades matemáticas, e isto não é diferente quando se trata de modelagem matemática.

A adoção da perspectiva sociocrítica para as atividades de modelagem matemática é um elemento que favorece os enlaces com a Educação Matemática Crítica, como recomenda Araújo (2009). A autora defende inclusive projetos de modelagem voltados para a promoção do diálogo e da democracia, citando como exemplo o trabalho de Jacobini e Wodewotzki (2006), que coloca a modelagem matemática num cenário pautado pela participação dos estudantes em discussões políticas, suas consequências e o envolvimento desses estudantes em ações comunitárias, ampliando a problematização para o contexto social real. Outro trabalho importante sob a perspectiva da modelagem matemática e a Educação Matemática Crítica é de autoria de Silva (2019), que propôs atividades de modelagem para alunos em vulnerabilidade social, que discutiam temas como desperdício de comida e mudança tarifária, permeados por questões sociais, econômicas, ambientais e culturais, no sentido de desenvolver a conscientização sobre esses temas e ações para transformar o contexto onde se inserem, o que pode desencadear uma discussão mais ampla, no que diz respeito à justiça social.

Gerardo (2008) coloca que a Matemática tem um poder econômico, político e social e que muitos modelos matemáticos trazem uma intencionalidade que não favorece algumas

Tangram - Revista de Educação Matemática, Dourados - MS - v.3 n.2, pp. 71-101 (2020) 


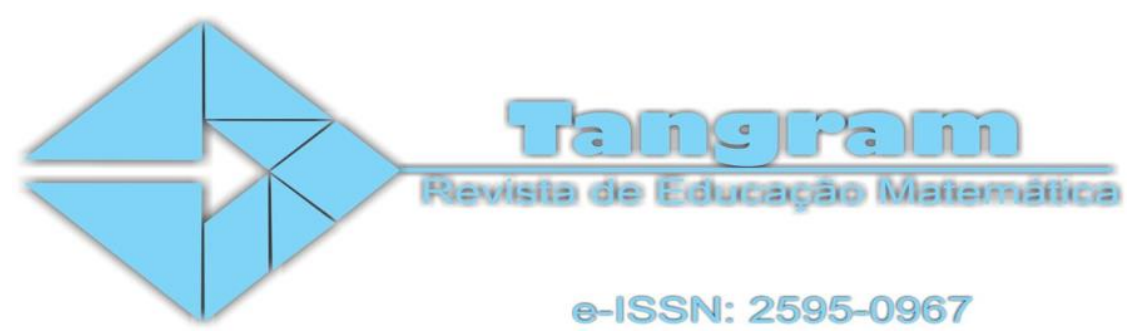

classes sociais. A autora questiona também porque certos modelos não contemplam determinadas variáveis uma vez que os contextos sociais são complexos e diferentes:

$\mathrm{Na}$ estrutura da argumentação, os responsáveis pelo modelo fazem uma interpretação da realidade e determinam quais os aspectos que irão valorizar ou desprezar, dado que não é viável considerar todas as variáveis. Um modelo não é a realidade, é apenas uma aproximação da realidade em estudo. Esta interpretação do real é influenciada pelo background e foreground de cada elemento envolvido no processo e pelos interesses políticos para uma sociedade. As bases sociais que servirão para a reformulação do modelo poderão ser determinadas em função de interesses políticos ou econômicos, já que os custos relacionados com a sua aplicação irão influenciar a necessidade de ser corrigido ou não, no sentido de melhorar o modelo com minimização de custos. (Gerardo, 2008, p. 05)

Por isso, Gerardo (2008) pontua a importância dos sujeitos serem conscientes que as aplicações da Matemática têm implicações para suas vidas e também para o exercício da cidadania. Gerardo (2008, p. 06) cita Gutstein (2006) que “propõe uma abordagem da Matemática escolar que procure uma profunda compreensão da sociedade e que prepare os alunos para serem participantes ativos na sociedade democrática”. Para Guststein (op. cit) este tipo de abordagem traz benefícios em relação à justiça social e da própria aprendizagem da Matemática na medida em que os alunos passam a enxergá-la como uma ferramenta de análise para compreender a realidade e mudá-la. E a justiça social pela Matemática segundo Gerardo (2008, p. 07) "exige conscientização, intencionalidade, reflexão crítica e solidariedade", recomendando que se incluam questões sociais e econômicas reais nas aulas de Matemática, e as atividades de modelagem matemática constituem uma oportunidade para isso, sendo necessário repensar o currículo. E aqueles protestos de 2013 contra o reajuste da tarifa do ônibus aqui narrados se inserem nesse cenário onde a justiça social pode desencadear discussões sobre como os modelos matemáticos para o cálculo das tarifas são elaborados, qual o papel da Matemática nesse contexto social no qual milhares de pessoas, muitas com um salário mínimo mensal arcam (ou não conseguem arcar) com os aumentos, que impactos trazem para as famílias, dentre outras discussões pautadas pela Educação Matemática Crítica, que também tornam as aulas mais interessantes e atrativas, por se

Tangram - Revista de Educação Matemática, Dourados - MS - v.3 n.2, pp. 71-101 (2020) 


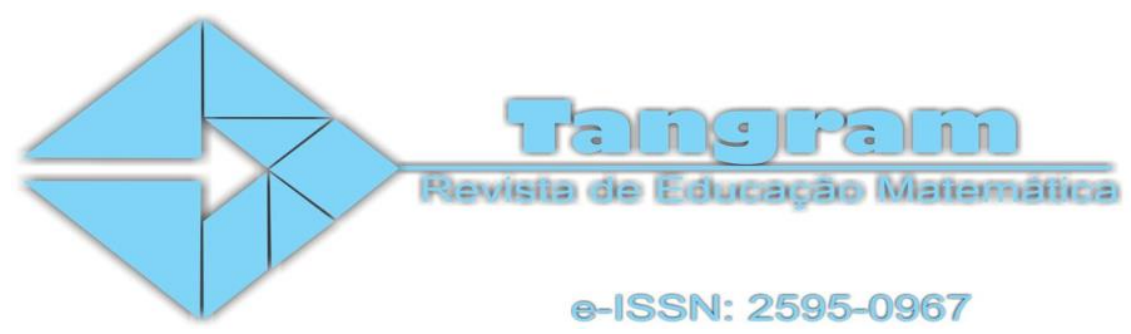

conectarem com os problemas enfrentados por muitos pais de alunos que utilizam o transporte público para trabalhar.

Por fim cabe reiterar, que D’Ambrosio (2013, p. 5) coloca que um dos propósitos dos sistemas educacionais é "promover a cidadania (que prepara o indivíduo para estar integrado e produtivo na sociedade), obtida pela transmissão de valores e esclarecimento dos direitos e responsabilidades na sociedade" desde que não seja uma cidadania submissa e para tanto, a Matemática não pode reduzir-se a reprodução de regras, mecanização de procedimentos, descontextualizada, mas que possua instrumentos comunicativos, analíticos/simbólicos e tecnológicos, que constituem uma nova proposta curricular, denominada de trivium, que instrumentalize os sujeitos para lidar com a complexidade do mundo e da sociedade, daí a Educação Matemática Crítica ser importante para se desenvolver a competência democrática, dialógica e emancipatória como lembram Skovsmose (1992, 2001, 2005, 2007, 2008), Freire (1970) e Giroux (1997) .

\section{Referências}

Araújo, J. L. (2009). Uma abordagem sócio-crítica da Modelagem Matemática: a perspectiva da educação matemática crítica. Alexandria - Revista de Educação em Ciência e Tecnologia, v.2, n.2, p.55-68, jul.

Blog do Planalto (2013) . Corte de impostos federais permite queda de até 7,23\% na tarifa de ônibus. Recuperado em 10 julho, 2013, de http://blog.planalto.gov.br/corte-deimpostos-federais-permite-queda-de-ate-723-na-tarifa-de-onibus/.

Brasil. (2018). Base nacional comum curricular. Recuperado em 30 março, 2020 de http://basenacionalcomum.mec.gov.br/images/BNCC_EI_EF_110518_versaofinal site.pdf.

Brasil. (2000). $L D B$ - Lei $n^{\circ}$ 9.394/96. Estabelece as diretrizes e bases da Educação Nacional. Brasília: MEC, 2000.

Borba, M.C. \& Skovsmose, O. (2001). A ideologia da certeza em educação matemática. In: Skovsmose, O. Educação matemática crítica: a questão da democracia. Papirus, Campinas, SP, 2001.

Tangram - Revista de Educação Matemática, Dourados - MS - v.3 n.2, pp. 71-101 (2020) 


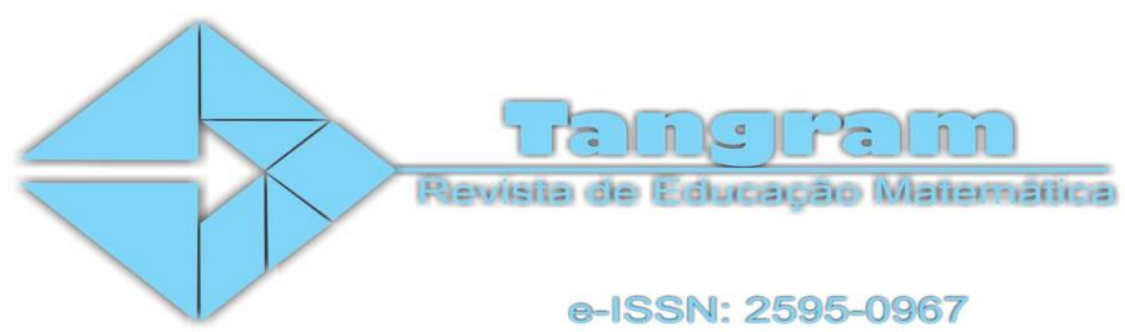

Câmara dos Deputados. Há 25 anos era eleita a Assembleia Nacional Constituinte. Recuperado em 12 setembro, 2013, de http://www2.camara.leg.br/comunicacao/institucional/noticias-institucionais/ha25-anos-era-eleita-a-assembleia-nacional-constituinte.

Castells, M. (1999). A era da informação: economia, sociedade e cultura. São Paulo: Paz e Terra.

Costa, A. B.; Sousa JR, J. G. (2009). O Direito Achado na Rua: uma ideia em movimento. In: Costa, A. B. et al (Org.). O Direito Achado na Rua: introdução crítica ao direito à saúde. Brasília: CEAD UnB, p. 15-28.

D'Ambrosio, U. (2013). Um sentido mais amplo de ensino da matemática para a justiça social. Recuperado em 30 março, 2020 de http://ciaem-redumate.org/memoriasicemacyc/Conferencia_plenaria,_D'Ambrosio.pdf.

D'Ambrosio, U. (2018). Etnomatemática, justiça social e sustentabilidade. Estudos Avançados, 32(94), 189-204.

D’Ambrosio, U. (1986). Da realidade à ação: reflexões sobre educação e matemática. São Paulo: Sumus.

Ennis, R.H. (1991). Critical thinking: a streamlined conception. Teaching Philosophy, 14 (1), 5-25.

D'Ambrosio, U. (1993). Critical thinking assessment. Theory into Practice, 32 (3), 179186, 1993.

D'Ambrosio, U. (1996). Critical thinking dispositions: Their nature and assessability. Informal Logic, 18 (2/3), 165-182.

D'Ambrosio, U. (2011). The nature of critical thinking: an outline of critical thinking dispositions and abilities. 2011. Recuperado em 02 junho, 2012, de http://faculty.education.illinois.edu/rhennis/documents/TheNatureofCriticalThinki ng_51711_000.pdf.

Freire, P. (1970). Pedagogia do Oprimido. Rio de Janeiro: Editora Paz e Terra.

Giroux, H. (1997). Os professores como intelectuais. Porto Alegre: Artes Médicas.

Guimarães, U. (1987). Trecho do discurso proferido pelo deputado Ulysses Guimarães durante a abertura dos trabalhos da Assembleia Nacional Constituinte em 1987. $\begin{array}{lllll}\text { Recuperado } & \text { em } & 12 & \text { setembro, } & 2013,\end{array}$ http://www2.camara.leg.br/comunicacao/institucional/noticias-institucionais/ha25-anos-era-eleita-a-assembleia-nacional-constituinte.

Tangram - Revista de Educação Matemática, Dourados - MS - v.3 n.2, pp. 71-101 (2020) 


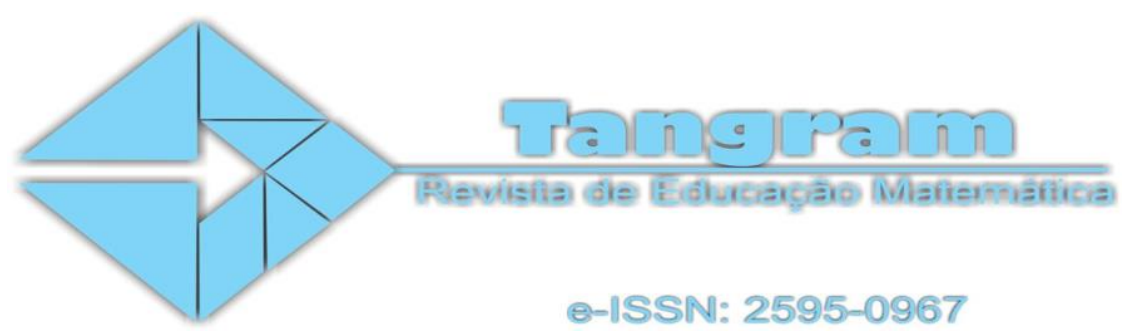

Guimarães, U. (1988). Trechos do discurso do deputado Ulysses Guimarães durante a promulgação da Constituição de 1988. Recuperado em 12 setembro, 2013, de http://www2.camara.leg.br/camaranoticias/radio/materias/CAMARA-EHISTORIA/339277--INTEGRA-DO-DISCURSO-PRESIDENTE-DAASSEMBLEIA-NACIONAL-CONSTITUINTE,--DR.-ULISSES-GUIMARAES(10-23).html.

Instituto de Pesquisa Econômica Aplicada (IPEA). (2013). Nota técnica: Tarifação e financiamento do transporte público urbano. Recuperado em 20 agosto, 2013 de http://www.ipea.gov.br/participacao/images/pdfs/notatecnicadirur_transpostetarifa s.pdf.

Jornal O Estado de São Paulo. (2013). MP questiona Haddad sobre IPTU financiar tarifa de onibus. Recuperado em 17 novembro, 2013, de http://www.estadao.com.br/noticias/cidades,mp-questiona-haddad-sobre-iptufinanciar-tarifa-de-onibus, $1083043,0 . \mathrm{htm}$.

Lyra Filho, R. (2005). A ciência do Direito. Revista Notícia do Direito Brasileiro, n. 11, Brasília, 269-288.

Lyra Filho, R. (2001). O que é Direito. 17. ed. Coleção Primeiros Passos - 62. São Paulo: Brasiliense.

Matsuki, E. (2013). De 2000 a 2012, tarifas de ônibus sobem 67 pontos acima da inflação, diz Ipea. Recuperado em 10 julho, 2013, de http://noticias.bol.uol.com.br/ultimasnoticias/brasil/2013/07/04/de-2000-a-2012-tarifas-de-onibus-sobem-67-pontosacima-inflacao-diz-ipea.htm.

Moreira, M. A. (2005). Aprendizagem significativa crítica. Porto Alegre: UFRGS.

Nalini, J. R. (2008). Justiça: aliada eficaz da natureza. In: TRIGUEIRO, A. (Org.). Meio ambiente no século 21: 21 especialistas falam da questão ambiental nas suas áreas de conhecimento. Campinas: Armazém do Ipê.

Nicolescu, B. (1999). O manifesto da transdisciplinaridade. São Paulo: Triom.

Oliveira, L. G. (2008). O pensamento jusfilosófico de Roberto Lyra Filho: descrição histórico-política e aplicação ao Direito Penal. 2008. 171f. Dissertação (Mestrado em Direito) - Faculdade de Direito, Universidade Metodista de Piracicaba, Piracicaba.

Tangram - Revista de Educação Matemática, Dourados - MS - v.3 n.2, pp. 71-101 (2020) 


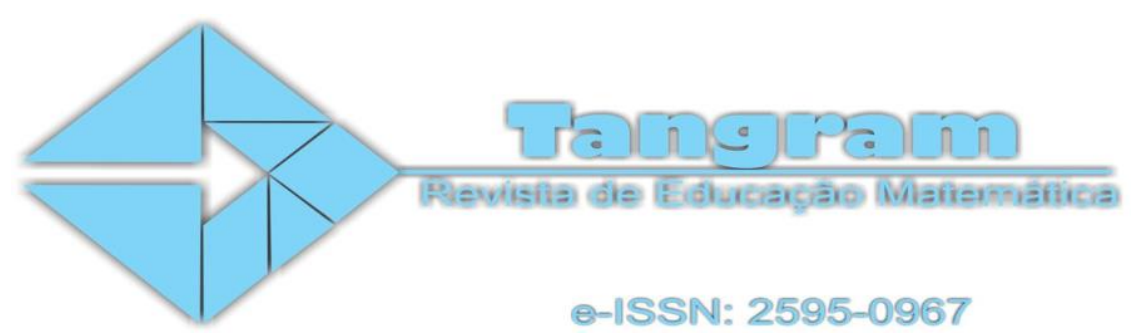

Passos, C. M. (2008). Etnomatemática e educação matemática crítica. 2008. $150 \mathrm{f}$. Dissertação (Mestrado) - Faculdade de Educação, Universidade Federal de Minas Gerais.

Portal G1. (2013). Decisão do presidente do TJ mantém aumento do IPTU em São Paulo. Recuperado em 17 novembro, 2013, de http://g1.globo.com/saopaulo/noticia/2013/11/decisao-do-presidente-do-tj-mantem-aumento-do-iptu-emsao-paulo.html.

Prefeitura de Porto Alegre (2013). Manual de cálculo da tarifa de ônibus de Porto Alegre. $\begin{array}{lllll}\text { Recuperado em } & 17 & \text { agosto, de }\end{array}$ http://lproweb.procempa.com.br/pmpa/prefpoa/eptc/usu_doc/manual_calculo_tari fario_internet_18jul2013_pdf.

Prefeitura do Rio de Janeiro (2013). Pacto pela transparência nos transportes. Recuperado em 17 agosto, 2013, de http://estaticog1.globo.com/2013/06/25/PactopelaTransparencianosTransportes.pd f.

Revista Exame (2013). STJ mantém suspensão do aumento do IPTU em SP. Recuperado em 19 fevereiro 2014, de http://exame.abril.com.br/economia/noticias/stj-mantemsuspensao-do-aumento-do-iptu-em-sp.

Silva, C. (2011). A perspectiva sociocrítica da Modelagem Matemática e a Aprendizagem Significativa Crítica: possíveis aproximações. 2011. 145 f. Dissertação (Mestrado em Educação para a Ciência e a Matemática ) - Universidade Estadual de Maringá, Maringá.

Silva, R. M. (2019). Atividades de modelagem matemática com estudantes em vulnerabilidade social: uma análise à luz da educação matemática crítica. 2019.116 f. Dissertação (Mestrado em Ensino de Matemática) - Universidade Tecnológica Federal do Paraná, Londrina, 2019.

Silva, M. S.; Barbosa, J. C. \& Oliveira, A. M. P. (2012). O sequenciamento do ambiente de modelagem matemática a partir do contato com materiais curriculares educativos. Acta Scientiae, Canoas, 14 (2), 240-259, maio/ago.

Silva, M. S.; Barbosa, J. C. \& Oliveira, A. M. P. (2013). Materiais curriculares educativos sobre modelagem matemática e a recontextualização pedagógica operada por professores iniciantes. Revista Iberoamericana de Educación Matemática, 34, p. 47-67, jun.

Tangram - Revista de Educação Matemática, Dourados - MS - v.3 n.2, pp. 71-101 (2020) 


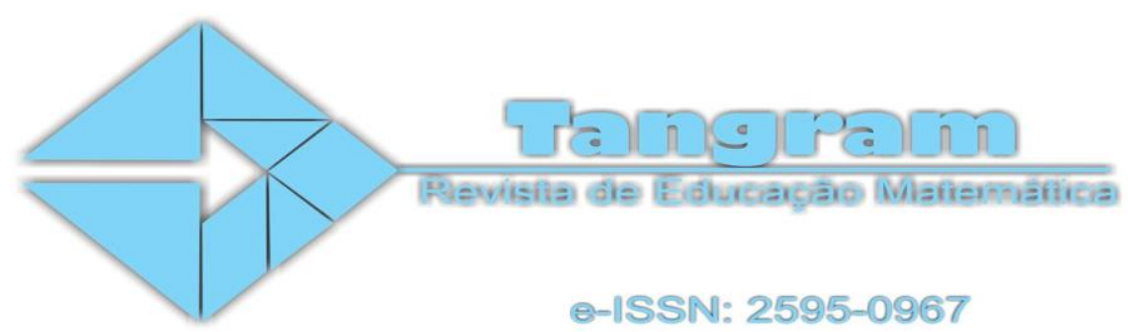

Skovsmose, O. (1992). Competência democrática e conhecimento reflexivo em matemática. Recuperado em 17 agosto, 2013, de http://www.educ.fc.ul.pt/docentes/jponte/fdm/textos/skovsmose.doc .

Skovsmose, O. (2001). Educação matemática crítica: a questão da democracia. Campinas, SP: Papirus.

Skovsmose, O.. (2007). Educação crítica: incerteza, matemática, responsabilidade. São Paulo: Cortez.

Skovsmose, O.. (2005). Guetorização e globalização: um desafio para a Educação Matemática

Zetetike, 13 (24) - 113 - 142, jul./dez.

Skovsmose, O.. (2008). Desafios da reflexão em educação matemática crítica. Campinas, SP: Papirus.

Sousa, N. H. B. et al. (2010). O Direito Achado na Rua: 25 anos de experiência universitária. Revista ParticipAção - Revista do Decanato de Extensão da Universidade de Brasília, ano 12, 18, 43-53.

Sousa JR, J. G. (2008a). Direito como liberdade: o direito achado na rua, experiências populares emancipatórias de criação do Direito. 2008. 338 f. Tese (Doutorado em Direito) - Faculdade de Direito, Universidade de Brasília, Brasília.

Sousa JR, J. G (2008b). A construção social da cidadania: o Direito Achado na Rua. 2008b.

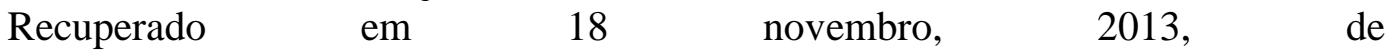
http://www.fd.unb.br/index.php?option=com_content\&view=article\&id=247\%3A a-construcao-social-da-cidadania-o-direito-achado-na-rua\&catid=180\%3 Acadnoticias-menor-impacto\&Itemid=2829\&lang=br.

Stillman, G. (2012). Applications and modelling research in secondary classrooms: what have we learnt? Recuperado em 12 julho, 2012, de http://www.icme12.org/upload/submission/1923_F.pdf.

Contribuições dos Autores

Tangram - Revista de Educação Matemática, Dourados - MS - v.3 n.2, pp. 71-101 (2020) 


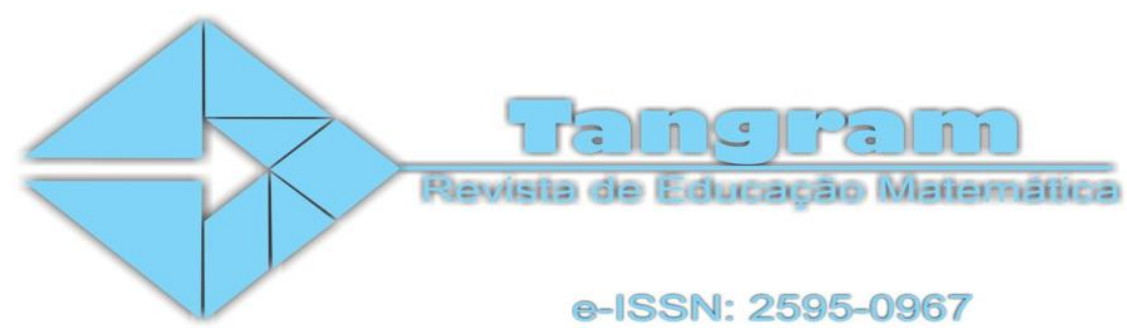

$1^{\text {a }}$ autor: conceitualização; curadoria de dados; análise formal; investigação; metodologia; visualização; redação - rascunho original; redação - revisão e edição.

$2^{\mathrm{a}}$ autor: conceitualização; curadoria de dados; análise formal; investigação; metodologia; visualização; redação - rascunho original; redação - revisão e edição.

Tangram - Revista de Educação Matemática, Dourados - MS - v.3 n.2, pp. 71-101 (2020) 